\title{
Distribution of rorquals and Atlantic cod in relation to their prey in the Norwegian high Arctic
}

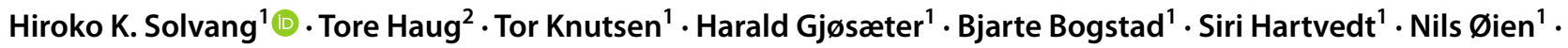 \\ Ulf Lindstrøm ${ }^{2,3}$
}

Received: 4 February 2020 / Revised: 21 February 2021 / Accepted: 22 February 2021 / Published online: 14 March 2021

(c) The Author(s) 2021

\begin{abstract}
Recent warming in the Barents Sea has led to changes in the spatial distribution of both zooplankton and fish, with boreal communities expanding northwards. A similar northward expansion has been observed in several rorqual species that migrate into northern waters to take advantage of high summer productivity, hence feeding opportunities. Based on ecosystem surveys conducted during August-September in 2014-2017, we investigated the spatial associations among the three rorqual species of blue, fin, and common minke whales, the predatory fish Atlantic cod, and their main prey groups (zooplankton, 0 -group fish, Atlantic cod, and capelin) in Arctic Ocean waters to the west and north of Svalbard. During the surveys, whale sightings were recorded by dedicated whale observers on the bridge of the vessel, whereas the distribution and abundance of cod and prey species were assessed using trawling and acoustic methods. Based on existing knowledge on the dive habits of these rorquals, we divided our analyses into two depth regions: the upper $200 \mathrm{~m}$ of the water column and waters below $200 \mathrm{~m}$. Since humpback whales were absent in the area in 2016 and 2017, they were not included in the subsequent analyses of spatial association. No association or spatial overlap between fin and blue whales and any of the prey species investigated was found, while associations and overlaps were found between minke whales and zooplankton/0-group fish in the upper $200 \mathrm{~m}$ and between minke whales and Atlantic cod at depths below $200 \mathrm{~m}$. A prey detection range of more than $10 \mathrm{~km}$ was suggested for minke whales in the upper water layers.
\end{abstract}

Keywords Blue whale $\cdot$ Fin whale $\cdot$ Minke whale $\cdot$ Cod $\cdot$ Zooplankton $\cdot$ Predator-prey associations

\section{Introduction}

Recent warming in the Barents Sea has led to changes in the spatial distribution of both zooplankton and fish, with boreal communities expanding northwards. These climatic changes have caused a marked shift in the distribution of water masses, and as a result, the favorable thermal habitat for boreal zooplankton, such as Calanus finmarchicus and krill (Thysanoessa spp.), have expanded, whereas Arctic zooplankton (e.g., the amphipod Themisto libellula) have

Hiroko K. Solvang

hiroko.solvang@hi.no

1 Institute of Marine Research, Nordnes, PO Box 1870, 5817 Bergen, Norway

2 Institute of Marine Research, Fram Center, Langnes, PO Box 6606, 9296 Troms $\varnothing$, Norway

3 Department of Arctic and Marine Biology, Arctic University of Norway, 9296 Troms $\varnothing$, Norway retreated further north (Zhukova et al. 2009; Orlova et al. 2010, 2015; Arthun et al. 2012; Dalpadado et al. 2012; Eriksen et al. 2017). The observed changes have in turn caused changes in the spatial distribution of demersal fish communities, as boreal communities have expanded northwards with the associated food-web shifts (Fossheim et al. 2015; Kortsch et al. 2015). Both surveys and fisheries in the northern Barents Sea show indications of recent northward expansion of boreal species including Atlantic cod (Gadus morhua), haddock (Melanogrammus aeglefinus), and capelin (Mallotus villosus) (Haug et al. 2017). Expansion of boreal demersal species has resulted in increased predation pressure not only on forage fish stocks such as capelin and the endemic polar cod (Boreogadus saida) but also on the Arctic benthic fish community that has retracted north- and northeast-wards to areas bordering the deep polar basin (Fossheim et al. 2015). Recent studies of cod in Fram Strait show that this species may even leave the shelf areas for deeper waters 
to feed on mesopelagic organisms, including crustaceans and fish (Ingvaldsen et al. 2017).

Some key Arctic endemic marine mammals, including the three cetaceans, bowhead whales (Balaena mysticetus), belugas (Delphinapterus leucas), and narwhals (Monodon monoceros), have adapted to life at high latitudes and spend their entire life within the region (Kovacs et al. 2011). Other species, such as blue whales (Balaenoptera musculus), fin whales (Balaenoptera physalus), humpback whales (Megaptera novaeangliae), and minke whales (Balaenoptera acutorostrata) (also denoted as rorquals or Balaenopteridae), migrate to the northern waters to take advantage of high summer productivity and, hence, feeding opportunities but spend the rest of the year in their largely temperate distributional ranges (Haug et al. 2017; Moore et al. 2019). They often forage on zooplankton and pelagic fishes at ocean fronts and other areas where upwelling stimulates high productivity (Kovacs and Lydersen 2008). Following the receding sea ice, the ongoing northward expansions by rorqual species will likely cause competitive pressure on the endemic Arctic cetacean species (Moore and Huntington 2008; Kovacs et al. 2011; Skern-Mauritzen et al. 2011; Laidre et al. 2015; Haug et al. 2017; Vacquie-Garcia et al. 2017; Storrie et al. 2018). Competition for food such as krill, between marine mammals and the currently large stock of Atlantic cod in the Barents Sea, may also affect marine mammals inhabiting the same areas (Bogstad et al. 2015).

While blue whales are known to feed exclusively on zooplankton, the diets of fin and minke whales usually comprise both zooplankton and several fish species (Christensen et al. 1992a; Haug et al. 2002). Despite spatial mobility and flexibility in feeding, changes in the availability of prey as well as the presence of competitors have been shown to affect body condition and fecundity in several baleen whale species (Haug et al. 2002; William et al. 2013; George et al. 2015; Solvang et al. 2017). Over the period 1992-2013, a negative trend was observed in the body condition of northeast Atlantic minke whales (Solvang et al. 2017). This was also a period of increasing Atlantic cod abundance, and it has been suggested that cod could outcompete whales for common food resources (Bogstad et al. 2015). This is the background for also including Atlantic cod abundance in the current analyses.

Existing knowledge on the dive patterns of rorquals, in particular, how deep they may dive to pursue food in the study area, is restricted to energy-expenditure experiments where instrumented minke whales were observed to dive to depths ranging from 15 to $65 \mathrm{~m}$ (Blix and Folkow 1995). In their studies of whale distribution in relation to prey abundance off the Antarctic Peninsula, Friedlaender et al. (2006) observed that the distribution of minke and humpback whales was coupled with krill abundance in the upper (15-100 m) and middle (100-300 m) depths of the water column. In West Greenland waters, Laidre et al. (2010) observed that the biomass of krill at given depths $(150 \mathrm{~m}$ or more, particularly the strata between 150 and $175 \mathrm{~m}$ ) was predictive of fin, minke, and humpback whale presence. The North Pacific off the west coast of America seems to be the area where most dedicated studies of rorqual foraging and diving patterns have been carried out in recent years, particularly for blue whales but also for fin whales (Lagerquist et al. 2000; Croll et al. 2001; Goldbogen et al. 2013; Friedlaender et al. 2015; Hazen et al. 2015). These studies show that both blue and fin whales may forage well below the 200-m depth, blue whales even down to $300 \mathrm{~m}$, and that some of these depth regions may be where the whales gain most of their energy.

During the years 2014-2017, ecosystem surveys were conducted in August-September in the Arctic Ocean to the west and north of Svalbard (Fig. 1). Sampling included all trophic levels from phytoplankton to whales, as well as chemical and physical properties of the water masses in the area. Here, we investigate possible spatial relationships and associations among the three rorqual species (blue, fin and minke whales), the predatory fish Atlantic cod, and their potential prey in their new foraging areas in the Arctic Ocean.

Our analyses included different statistical approaches and had several sub-goals: First, we described the distribution of rorquals, Atlantic cod, and relevant prey categories in the area. Second, we explored potential spatial associations between the whales and their prey, using a spatial overlap analysis previously used by Volkenandt et al. (2016). Third, we performed a chi-square test to investigate possible independence in the relationship between rorquals and prey. Furthermore, we applied logistic regression models to investigate possible associations between the rorquals and various prey categories. Finally, we applied categorical data analyses to assess possible casual relationships between the rorquals and various alternative prey categories.

\section{Materials and methods}

Data were collected as part of the SI_ARCTIC 2014-2017 surveys conducted onboard the RV "Helmer Hanssen" from 19 August to 9 September 2014, 17 August-9 September 2015, 2-16 September 2016, and 21 August-7 September 2017. The study area was west and north of Svalbard (Fig. 1). Cruises consisted of transects from the shelf to the deeper basins in eastern Fram Strait, transects across the shelf from Northern Svalbard and over the shelf break, and transects along and partly into the drift ice north of Svalbard. This provided the opportunity to study changes across gradients in depth, in sea ice/water masses and currents, and along the Atlantic current. For this study, we used multiple gear 

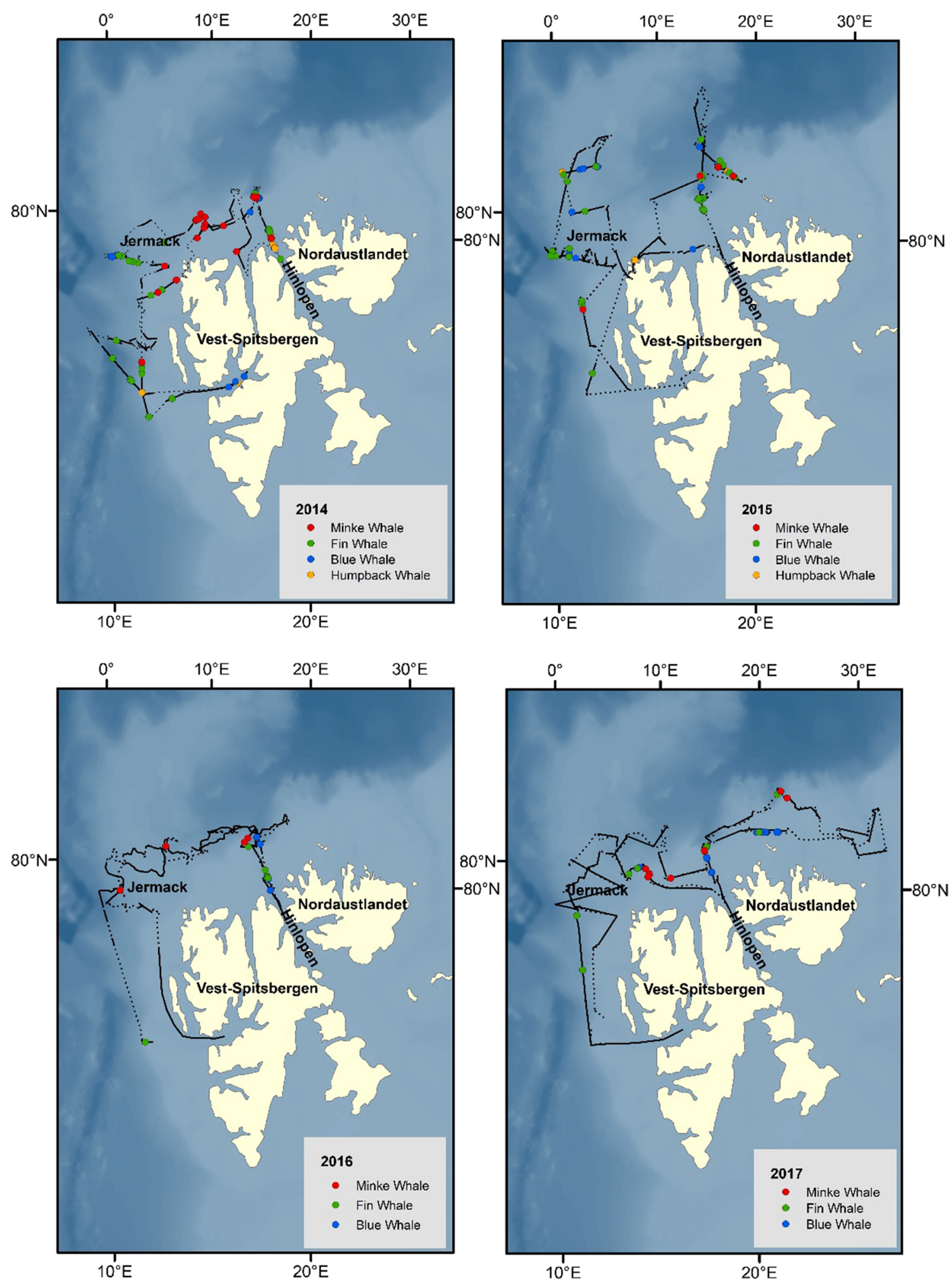

Fig. 1 Distribution of rorquals (blue, fin, humpback and minke whales) in the study area west and north of Svalbard in August-September of 2014-2017. The transects of the vessel are shown in each

year, where solid lines are areas with observations and dotted lines are areas without observations 
types to collect physical data and nets to sample zooplankton and fish to identify sources of backscatter recorded by the multifrequency acoustic sensors along the ship's transects. Acoustic backscatter was collected continuously along the track and used in real time to identify prey patches for targeted sampling. In addition to targeted sampling, sampling devices were deployed at regular intervals according to the sampling scheme. More information on the project, surveys, and sampling can be found in Ingvaldsen et al. (2017). The survey design did not allow for direct observations or measurements of details in whale behavior over longer periods on these feeding grounds, only where whales were present and not present. During the surveys, the presence of the whales was observed from the bridge of the vessel by dedicated whale observers, whereas the distribution and abundance of Atlantic cod and potential prey species were assessed using trawling and acoustic methods.

\section{Data sampling}

\section{Whale observations}

Rorquals were observed visually and recorded systematically along all cruise transects between stations. Two marine mammal observers from the vessel's bridge using binoculars each scanned a visual sector of $45^{\circ}$ from the bow to the port and starboard sides, respectively, and the positions of all mammal observations were noted. The observers provided an estimate of the relative angle to the ship track using an angle board. Time was registered automatically when a button was pressed to allow the relative position to be recorded on tape. The observers also recorded visibility and Beaufort sea state continuously, but no corrections were made for variations in these parameters. In cases with sea state above 6 Beaufort and/or meteorological visibility below $1000 \mathrm{~m}$, survey effort was suspended (Fig. 1).

\section{Prey depths}

Based on the information on feeding depths mentioned in the introduction, we divided our cod and prey data into two depth strata in our analyses: the upper $200 \mathrm{~m}$ of the water column and the layer deeper than $200 \mathrm{~m}$.

\section{Acoustic data collection}

Acoustic data for estimation of the distribution and abundance of zooplankton and fish in the water column were collected with calibrated EK60 echo sounder split beam systems running continuously at frequencies of 18,38 , and $120 \mathrm{kHz}$ at $1-\mathrm{ms}$ pulse duration. The echo sounders were connected to transducers mounted on a protruding instrument keel with transducer faces $\sim 3 \mathrm{~m}$ below the ship's hull, usually $\sim 8.5 \mathrm{~m}$ below the sea surface. To avoid the transducer's near field, only data deeper than $15 \mathrm{~m}$ were used in the analysis. The lower working threshold in terms of volume-backscattering strength $\left(S_{v}\right)$ in $\mathrm{dB}$ was set to $-82 \mathrm{~dB}$ re $1 \mathrm{~m}^{-1}$ (MacLennan et al. 2002). The vessel's EK60 systems are normally calibrated in January every year using standard methods (Foote et al. 1987; ICES 2015a, b) and are known to be very stable over time (Knudsen 2009). For the period 2010-2017, the vessel's 38-kHz EK60 system showed less than $0.1-\mathrm{dB}$ variation in $S_{v}$ transducer gain.

Multi-frequency scrutinizing and target strength analysis were conducted with the Large Scale Survey System (LSSS) post-processing application (Korneliussen et al. 2006, 2016), which was also used to export files for subsequent analysis by Matlab, Excel, or R (R version 3.2.3; R Core Team 2018). Data processing involved manual exclusion of noise (e.g., acoustic, electric, bubble, temporal noise from trawl sensors during trawl operations), correction of erroneous bottom detections, and surface-originated noise. The allocation of backscatter strength (in the form of $s_{\mathrm{A}}$ or Nautical Area Scattering Coefficient NASC, $\left(\mathrm{m}^{2} \mathrm{nmi}^{-2}\right)$, MacLennan et al. 2002) to various species or species groups and storage of these values in the database were done for $38-\mathrm{kHz}$ frequency. In the upper $200 \mathrm{~m}$, where the signal/ noise ratio on the $120-\mathrm{kHz}$ echo sounder is above acceptable levels, all three frequencies were considered when analyzing the frequency response, while below this depth only 18 and $38 \mathrm{kHz}$ were considered. Sequential thresholding was used to differentiate strong scatterers from weak scatterers. In the process, the lower threshold $\left(S_{v}\right)$ was moved from the standard $-82 \mathrm{~dB}$ upwards to a value where only the strongest scatterers remain visible on the echogram (e.g., $-60 \mathrm{~dB}$ ). The $s_{\mathrm{A}}$ corresponding to this $S_{v}$ threshold was then allotted to the species or species group normally known to have a target strength (TS) above this threshold. Subsequently, this $s_{\mathrm{A}}$ was subtracted from the total, and the remainder allotted to weak scatterers with TS below this threshold. In the Supplementary Material in Knutsen et al. (2017), additional details are presented on the use of 'sequential thresholding' and relative frequency response defined according to Korneliussen and Ona (2003) as $r(f) \equiv s_{v}(f) s_{v}(38 \mathrm{kHz})^{-1}$, where $s_{v}$ is the volume-backscattering coefficient and the response at the acoustic frequency $f$ is normalized to that at $38 \mathrm{kHz}$. Species composition data from pelagic trawl and zooplankton net data were used to determine which organisms were present and corroborate the interpretation of the acoustic data. The acoustic backscattering data in the reports were in the form of $s_{\mathrm{A}}$ for 10-m depth intervals in units of $\left(\mathrm{m}^{2} \mathrm{nmi}^{-2}\right)$. The relatively low noise level (Gjøsæter et al. 2017) permitted measurements down to about $800 \mathrm{~m}$, while the main concentrations of scatterers were found no deeper than 600 m (Knutsen et al. 2017). 
First, LSSS was used to allocate backscatter to the scattering categories "0-group fish", "Atlantic cod", "Haddock", "Capelin”, "Redfish", "Norway pout”, "Polar cod”, "Mesopelagic fish", "Blue Whiting", and "Others". The remaining backscatter that could not be assigned to any of these categories was assigned to the bulk category "Plankton". Only the categories "0-group fish", "Plankton", and "Atlantic cod" were used in the statistical analyses and visualized in the current work, except for example echograms showing the characteristics of the raw acoustic data. These four categories accounted for $94.4 \%$ of the integrated backscatter over the four years of the study. The $s_{\mathrm{A}}$-values allocated to these organism groups were used as a proxy for their biomass. The category "Plankton" is actually a mixed category composed of weak scatterers, and one major component of this category is larger macrozooplankton like krill and amphipods (c.f. Knutsen et al. 2017, Supplementary Material included).

The scrutinized $38-\mathrm{kHz}$ acoustic data for the four final prey categories were integrated vertically over the two different depth strata (above $200 \mathrm{~m}$ and below $200 \mathrm{~m}$ ), transformed to $\mathrm{S}_{\mathrm{A}}$ by $S_{\mathrm{A}}=10 \log 10\left(s_{\mathrm{A}}\right)$, and visualized to show the horizontal variability along the ship's cruise transects (Figs. 2, 3, 4).

\section{Biological sampling}

Samples of fish, micronekton, and zooplankton were collected with a variety of net and trawl systems. The type of gear used was decided based on the characteristics of the acoustic registrations. The purposes of biological sampling are manifold, but here we only used this information to determine the species of fish and zooplankton that were present at various depths and areas, corroborating the allocation of backscatter to species and groups. In addition, we also used the catch rates of Atlantic cod in the demersal trawl in a semiquantitative description of the geographic distribution of Atlantic cod near the sea floor. Sampling gears included a Campelen trawl (Engås and Godø 1989), a Harstad trawl (Nedreaas and Smedstad 1987; Godø et al. 1993; Dingsør 2005), a Macroplankton trawl (Melle et al. 2006; Wenneck et al. 2008; Krafft et al. 2010; Heino et al. 2011), an Åkra trawl (Valdemarsen and Misund 1995), a MIK-Ring Net (Munk 1993), a Multinet (Weikert and John 1981), and a twin WP2 (0.25 m²)-Juday (0.1 $\left.\mathrm{m}^{2}\right)$ net (Juday 1916; Working Party 2 1968; Skjoldal et al. 2019). A Multi-sampler, an opening and closing cod-end device with three net bags (Skeide et al. 1997; Wenneck et al. 2008), was attached to the Akra trawl during some deployments, allowing catches from up to three depth strata during individual hauls to be separated. The trawl speed varied between $\sim 2.5$ and 3.5 knots, depending on which trawl was being used, and the depth of trawling was monitored using a Scanmar depth sensor and trawl sonde, if available. The Macroplankton trawl was additionally equipped with a combined Scanmar speed/ symmetry sensor to allow the trawl speed through the water to be measured, thus allowing computation of the water volume filtered by the trawl.

\section{Statistical analyses}

Several statistical analyses were applied to investigate the relationships between rorquals and their prey. Depending on the method used, the data were re-formed by gridding or by transforming them to categorical data. All whale vs prey association analyses were restricted to whale sightings and prey categories that were present in all four years of the study. Selection of prey to be included was based on previous knowledge on the feeding habits of the whales (Christensen et al. 1992a; Haug et al. 2002; Windsland et al. 2007; Bogstad et al. 2015): zooplankton (krill, pelagic amphipods and smaller scatterers), 0-group fish, capelin, and Atlantic cod. The prey category "Capelin" was not encountered every year and, consequently, was removed from the final analyses.

\section{Spatial overlap between rorqual and prey}

In our study, whale sightings were aligned with the acoustic dataset by linking time and location of whale observations to time and location of prey abundance along the cruise transects, similar to methods presented in Volkenandt et al. (2016). However, while they calculated prey biomass for different circular areas based on the radial distances centered on whale sightings, our approach was based on the use of one-dimensional directional distances spanning $2,4,6, \ldots$, $50 \mathrm{~km}$ from the whale sighting position along the cruise track. Instead of calculated biomass, our prey abundance was based on the numbers of observed presence (1) or absence (0) in the acoustic survey for each prey category appearing at different distances from the whale sighting positions. The counted presence number (EMS_1.xlsx) was taken as a proportion calculated by dividing the counted number of present prey by the total number of whale sighting positions on the entire cruise track over the 4 years. In order to test whether any spatial overlap of rorquals and prey categories occurred, whale sightings were re-assigned by taking random locations on the cruise track. Presence-absence observations of prey were counted for each span, and the procedure was repeated 200 times to generate simulated random whale presence. The probability that positive prey abundance per whale location (observed versus simulated sightings) was significantly different from random were tested using a two-sided probability test of success (function prop.test, "stats" package, R software (R version 3.5.1 2018) as described by Volkenandt et al. (2016). When the test of disparity of probabilities was significant $(p<0.05)$, the null hypothesis was rejected, meaning that the spatial overlap 
Fig. 2 Acoustic registrations per $1 \mathrm{nmi}$ scrutinized as Cod along cruise track during autumn 2014-2017 on RV Helmer Hanssen west and north of Svalbard. a Integrated values of $\mathrm{s}_{\mathrm{A}}$ $\left(\mathrm{m}^{2} \mathrm{nmi}^{-2}\right)$ in the upper 200-m depth. b Integrated values of $s_{\mathrm{A}}\left(\mathrm{m}^{2} \mathrm{nmi}^{-2}\right)$ between $200 \mathrm{~m}$ and bottom. Data are presented as nautical area scattering strength $\left[S_{\mathrm{A}}, \mathrm{dB}\right.$ re $1 \mathrm{~m}^{2} \mathrm{nmi}^{-2}$ ), $\left.S_{\mathrm{A}}=10 \log 10\left(s_{\mathrm{A}}\right)\right]$. Black striped lines represent along-track locations where integrated $s_{\mathrm{A}}$-values were originally 0.0 . However, a small value of 0.0001 was added to all data in the linear domain so that $\log$ transformation and visualization could be accomplished
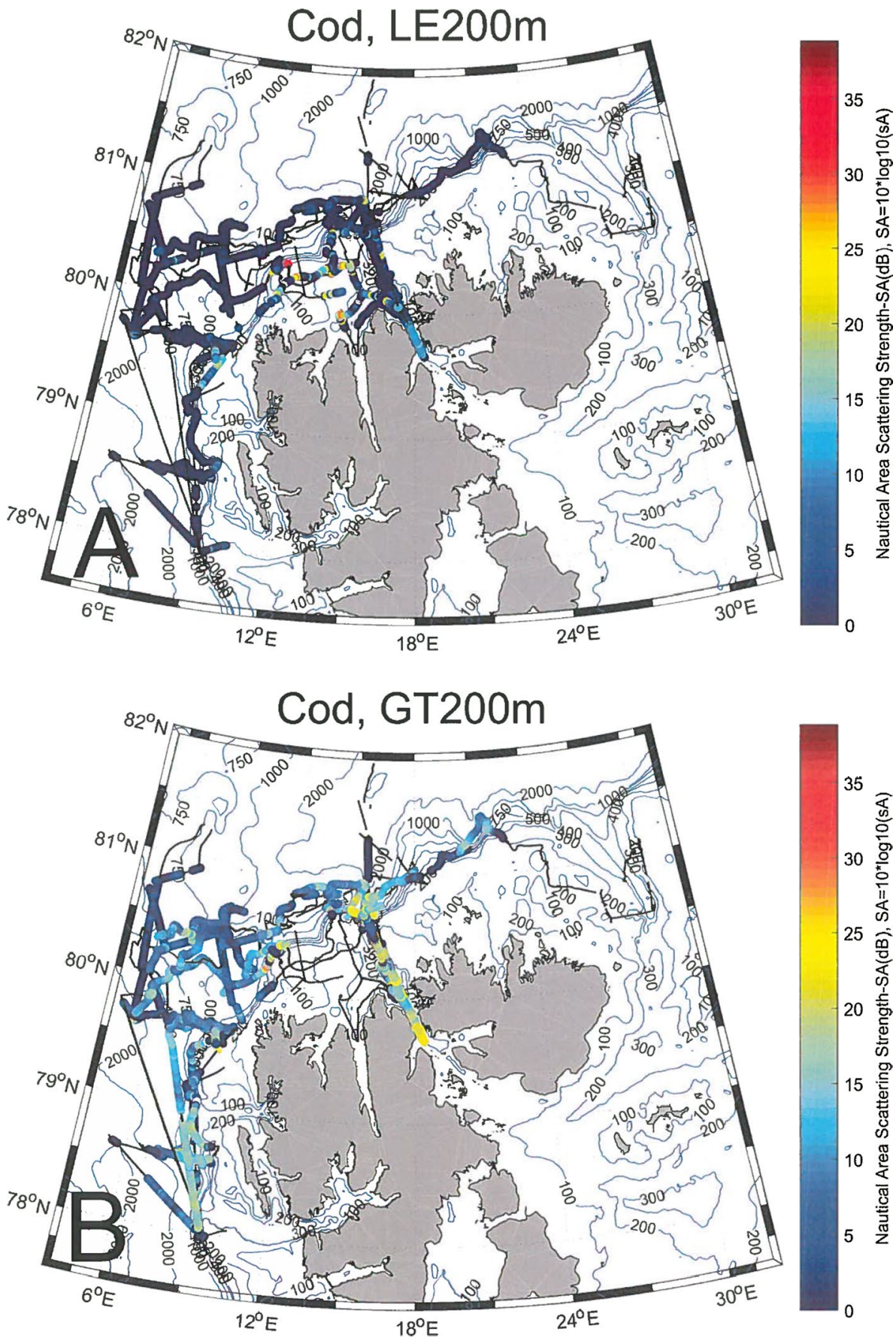

between rorquals and prey was not coincidental. The tests included sighting data for blue, fin, and minke whales, and the acoustic category data for Plankton, 0 -group fish, and Cod. A more detailed description of this analysis procedure is given in Text 1 of EMS.pdf.

\section{Test of independence between rorquals and prey}

To assess whether the relationship between whales and prey was independent, we performed chi-square testing of the sightings and acoustic data. In their study of baleen whales and prey associations in the Barents Sea, Skern-Mauritzen et al. (2011) used a grid cell size of $50 \mathrm{~km}$. For these analyses, we also adopted this grid cell size, but the data used were also aggregated in 25 - and $100-\mathrm{km}$ grid cells along the cruise track (see Text 2 of EMS.pdf). Furthermore, the data were aggregated into the two depth categories, i.e., above and below $200 \mathrm{~m}$. The numerical data of minke, fin and blue whale observations and the prey abundance were converted to 1 for all data larger than 0 , and to 0 for absence, and then 
Fig. 3 Acoustic registrations per $1 \mathrm{nmi}$ scrutinized as Plankton along cruise track during autumn 2014-2017 on RV Helmer Hanssen west and north of Svalbard. a Integrated values of $\mathrm{s}_{\mathrm{A}}\left(\mathrm{m}^{2} \mathrm{nmi}^{-2}\right)$ in the upper 200-m depth. b Integrated values of $s_{\mathrm{A}}\left(\mathrm{m}^{2} \mathrm{nmi}^{-2}\right)$ between $200 \mathrm{~m}$ and bottom. Data are presented as nautical area scattering strength $\left[S_{\mathrm{A}}, \mathrm{dB}\right.$ re 1 $\left.\left.\mathrm{m}^{2} \mathrm{nmi}^{-2}\right), S_{\mathrm{A}}=10 \log 10\left(s_{\mathrm{A}}\right)\right]$. Black striped lines represent along-track locations where integrated $s_{\mathrm{A}}$-values were originally 0.0 . However, a small value of 0.0001 was added to all data in the linear domain so that log-transformation and visualization could be accomplished
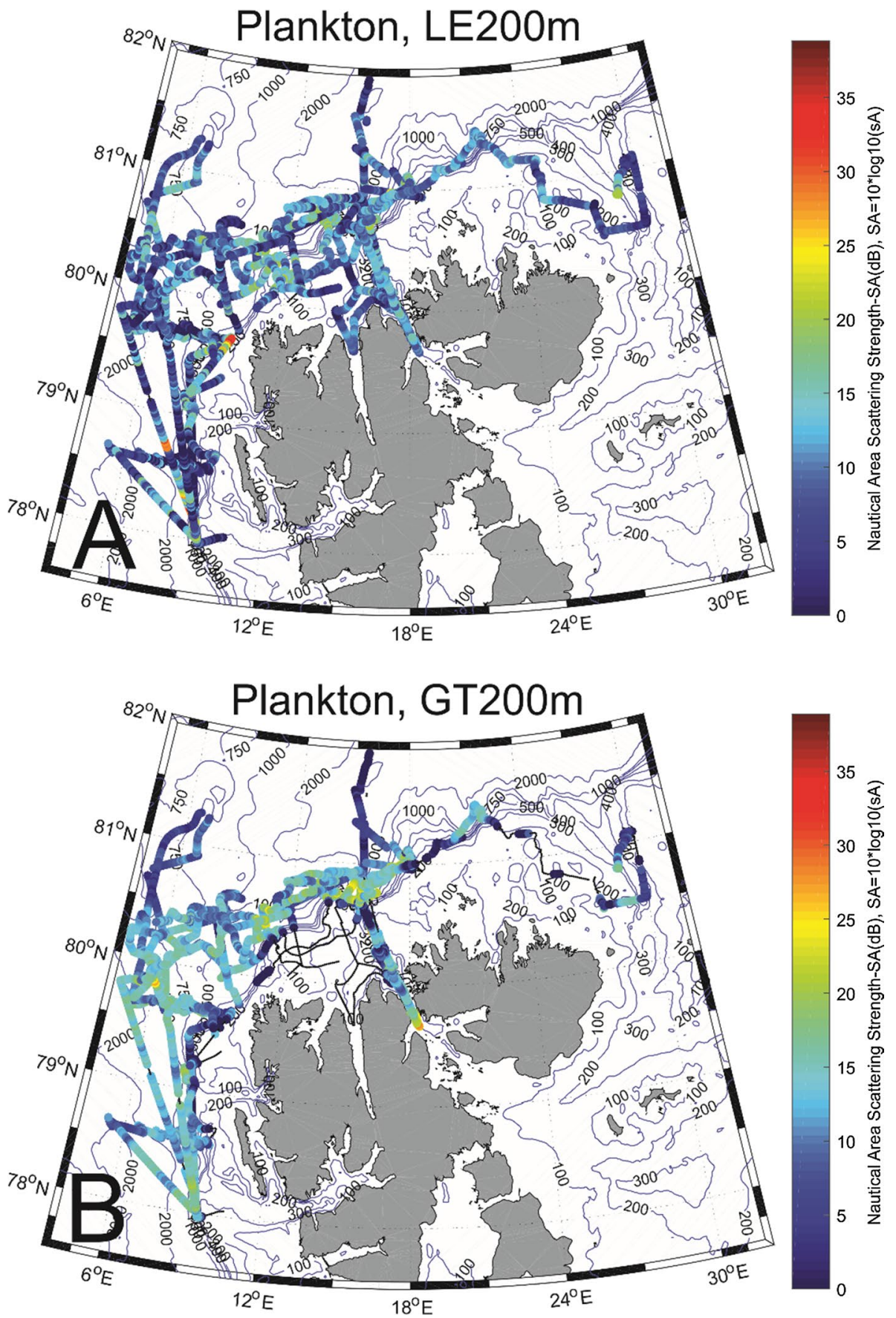

integrated for all years. Since capelin was not consistently observed in all four years, the species was excluded from this analysis, as were humpback whales. Two-way tables were generated for presence/absence of each whale species vs the Plankton, Cod, and 0-group fish categories. A chi-square test was run to test for potential difference between the expected frequencies and the observed frequencies using the Chisq. test function in $\mathrm{R}$ ( $\mathrm{R}$ version 3.5.1 2018).

\section{Logistic regression analyses}

To investigate whether certain prey groups were more or less likely to be present or absent when whales were present, logistic regression analyses were conducted. For these analyses, the data were again aggregated in 25-, 50-, and $100-\mathrm{km}$ grid cells along the cruise track (Text 2 of EMS. pdf). The whale sightings were all treated as presence or 
Fig. 4 Acoustic registrations per $1 \mathrm{nmi}$ scrutinized as 0 -group fish along cruise track during autumn 2014-2017 on RV Helmer Hanssen west and north of Svalbard. a Integrated values of $s_{\mathrm{A}}\left(\mathrm{m}^{2} \mathrm{nmi}^{-2}\right)$ in the upper 200-m depth. b Integrated values of $s_{\mathrm{A}}\left(\mathrm{m}^{2} \mathrm{nmi}^{-2}\right)$ between $200 \mathrm{~m}$ and bottom. Data are presented as nautical area scattering strength $\left[S_{\mathrm{A}}, \mathrm{dB}\right.$ re 1 $\left.\left.\mathrm{m}^{2} \mathrm{nmi}^{-2}\right), S_{\mathrm{A}}=10 \log 10\left(\mathrm{~s}_{\mathrm{A}}\right)\right]$. Black striped lines represent along-track locations where integrated $s_{\mathrm{A}}$-values were originally 0.0 . However, a small value of 0.0001 was added to all data in the linear domain so that log-transformation and visualization could be accomplished
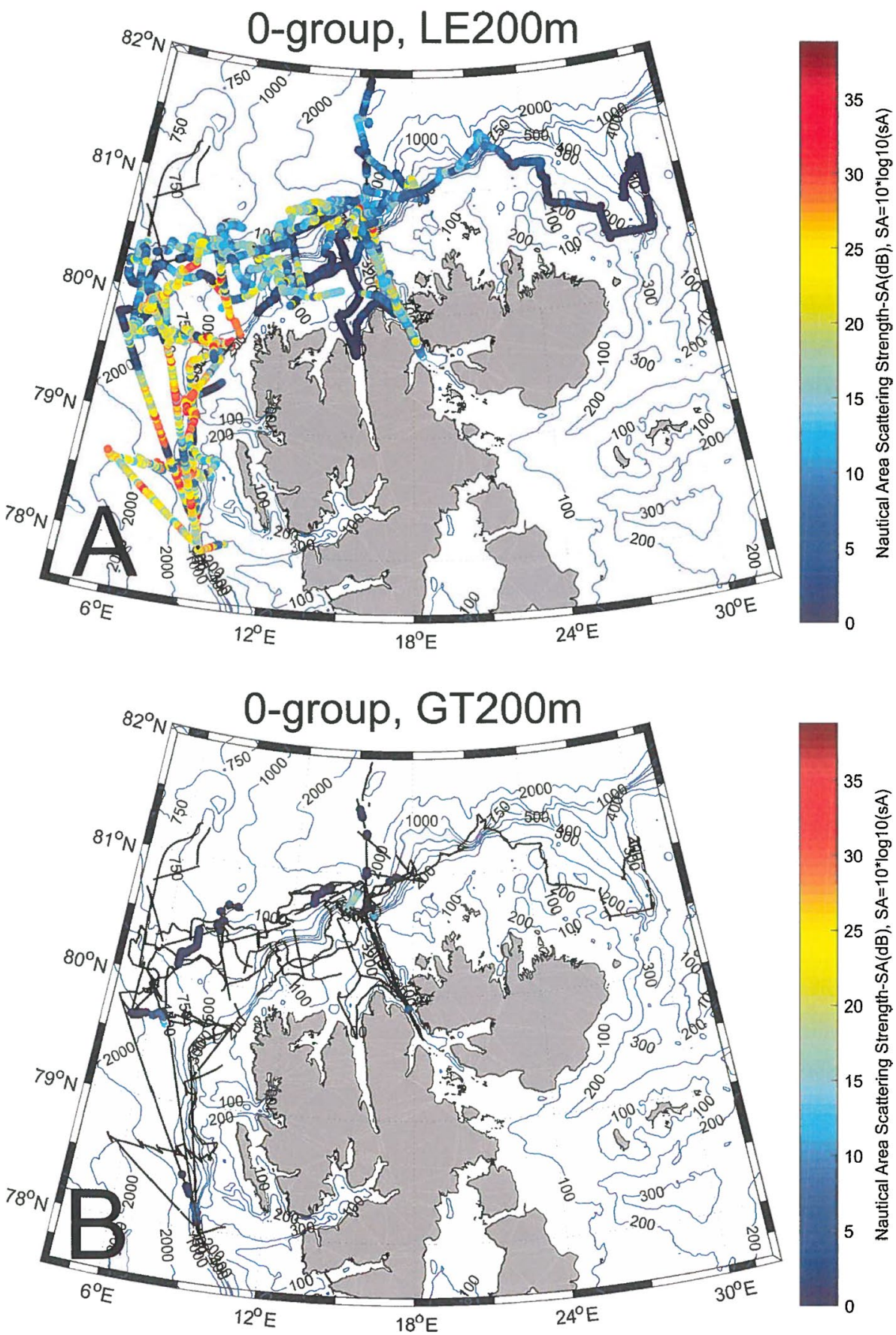

absence data. In this situation, a logistic regression model is appropriately given by

$\log \left(p_{i}\left(1-p_{i}\right)^{-1}\right)=\beta_{0}+\beta x_{i}, i=1, \ldots, n$,

where the objective variable is the appearance probability of the whale for each cell $i$ in a total of $n$ cells, $x_{i}$ is the estimated density of prey $i, \beta_{0}$ is the model's intercept, and $\beta$ is a coefficient of $x_{i}$. To these estimates, $z$-statistics was applied to assess whether the null hypothesis $\beta=0$ is accepted. Based on the obtained $p$-values, cases indicating insignificant estimates for $\beta$ may support an independent relationship between whale and prey-and this was investigated using a chi-square test as also done above. To avoid computational problems, zero prey $s_{\mathrm{A}}$-values were replaced by a very small real random number. We applied the model to one explanatory variable using a $\mathrm{glm}$ function in the $\mathrm{R}$ package ( $\mathrm{R}$ version 3.5.1 2018). The function $\mathrm{glm}$ performs the $z$-statistics testing for the estimated coefficients. 


\section{Causal inference by categorical data analysis}

The causal relationship among species provides an important contribution to our understanding of food webs within marine ecosystems, for example that of the Barents Sea (see Solvang et al. 2018). To explore the directional relationship of rorquals and their prey to our data, a categorical data analysis (Sakamoto and Akaike 1978; Katsura and Sakamoto 1980) was applied. While the independence test analyses in the previous subsection investigated the independent relationship between rorquals and prey, this method uses several selected species and explores which specific one has the strongest dependence on the other and searches for the optimal linkage among them. The data were again aggregated in $50-\mathrm{km}$ grid cells along the cruise track (see Skern-Mauritzen et al. 2011). Since the method is conducted on multidimensional contingency tables, we transferred the data to categorical data (= present or absent) for specified variables (response variables) and other variables (explanatory variables). The dependencies of the distribution of the response variables were derived to the explanatory variables. Every variable (i.e., both whale and prey abundance) is used as the response variable in consecutive runs. Specifying one variable as the response variable, the dependencies of its distribution on sets of other variables were investigated. Finally, we determined the predictor on which a specific variable has the strongest dependence and the optimal combination of predictors using the Akaike Information Criterion (AIC, see Akaike 1974). From the obtained best combination, the directional causal relationships were inferred. This procedure was performed using the $\mathrm{R}$ package CATDAP (Version 1.3.5, 2020), originally developed by Katsura and Sakamoto (1980) and updated by The Institute of Statistical Mathematics (CATDAP 2020).

\section{Results}

\section{Distribution of rorquals}

During the four years of surveys along the cruise track shown in Fig. 1, four species of rorquals were observed: blue, fin, minke and humpback whales. The latter species was, however, only observed in some numbers in the first survey year, rarely observed in 2015 and completely absent from the area in 2016 and 2017.

In general, all rorqual species were more frequently observed over the shelf areas to the north of Svalbard than over the shelf and along the shelf break to the west of the archipelago (Fig. 1). Blue and fin whales were the most abundant in all survey years, particularly in 2014 and 2015 when they also occurred to some extent to the west of Svalbard. These two species were also dominant in an apparent hotspot area for large whales north of Hinlopen Strait in all survey years (Fig. 1). Special priority was given to investigations near the ice edge in 2016 and 2017, which resulted in fewer cruise lines in open water. This may have contributed to the lower numbers of rorquals observed in these two years. In 2017, the ice conditions permitted operations further to the east than in the three previous years, and this resulted in more eastward observations both of blue and fin whales compared to the other years (Fig. 1).

\section{Distribution of Atlantic cod}

Atlantic cod was among the most dominant fish caught in demersal trawl during all four years of surveys. There was, however, large variability in catch rates among years and areas. Because the surveys were not designed for stock-size estimation, demersal trawl hauls were not distributed according to a survey design, and this may have affected the variability considerably. In general, Atlantic cod was found in largest concentrations on the shelf west and northwest of Svalbard. In most years, "hotspots" with higher concentrations were located northwest of Svalbard and north of Hinlopen Strait. In three of the years, Atlantic cod were dominant (by weight) in the demersal trawl catches.

The acoustic backscattering allocated to Atlantic cod corroborated the impression obtained from demersal trawl hauls, i.e., that the main concentrations of Atlantic cod were found close to the sea floor on the shelf near the coast (Fig. 2). Concentrations of Atlantic cod rapidly decreased farther from the coast. The acoustic registrations interpreted as cod at mesopelagic depths over deeper water were groundtruthed by catches in pelagic trawl hauls. The Atlantic cod observed pelagically over deep water occurred, however, in extremely low concentrations of 120-2900 specimens per $\mathrm{nmi}^{2}$ (Ingvaldsen et al. 2017).

\section{Distribution of prey}

The acoustic category Plankton was primarily represented by larger crustacean zooplankton such as krill, amphipods, and pelagic shrimps along with other weaker non-gasbearing invertebrate scatterers. If bottom depth were not too deep and conditions were appropriate, hyperbenthic shrimps could also be included with the Plankton category (cf. Hinlopen area is well known for its deep-sea shrimp (Pandalus borealis) stock and fishery, see Misund et al. 2016). Typically, there was some year-to-year variability and patchy distribution of zooplankton in the examined region, and regional coverage was also slightly different among years. Prey acoustic data from individual years have been pooled and are presented in Figs. 3 and 4 as "Plankton" and "0-group fish", respectively (see EMS_2.xlsx for description of the categories and data summary). In 2014, scattered 
patches of zooplankton were observed in the upper $200 \mathrm{~m}$ of the water column both on the slope and deep-water regions to the west of Svalbard and even some denser patches to the north of the Svalbard archipelago (Fig. 3a), extending from Hinlopen Strait to the slopes facing the deeper Arctic Ocean farther north. A similar pattern was observed for depths below $200 \mathrm{~m}$, particularly in the west (Fig. 3b).

Overall, the pattern in 2015 showed that fewer acoustic registrations could be attributed to zooplankton, except for a very restricted number of locations with quite high acoustic backscatter. Average $s_{\mathrm{A}}$ was more moderate for the years 2014 and 2017 in the upper $200 \mathrm{~m}$ of the water column, at $16.66 \mathrm{~m}^{2} \mathrm{nmi}^{-2}$ and $11.59 \mathrm{~m}^{2} \mathrm{nmi}^{-2}$, respectively. For 2015, the category PlankGT200m (Plankton below 200-m depth, see EMS_2.xlsx) showed very low values, since both average $s_{\mathrm{A}}$ and median $s_{\mathrm{A}}$ were very low $\left(6.96\right.$ and $4.71 \mathrm{~m}^{2}$ $\mathrm{nmi}^{-2}$, respectively). For the Plankton in the upper $200 \mathrm{~m}$ (PlankLE200m), the median $s_{\mathrm{A}}$ was $6.01 \mathrm{~m}^{2} \mathrm{nmi}^{-2}$, which was comparable to the average value below $200 \mathrm{~m}$ depth, although a few values on the west coast raised the average $s_{\mathrm{A}}$ to $26.03 \mathrm{~m}^{2} \mathrm{nmi}^{-2}$ for the epipelagic domain. The year 2016 was somewhat similar to 2015 for the epipelagic domain, with some higher values in the southwestern corner raising the average value to $27.34 \mathrm{~m}^{2} \mathrm{nmi}^{-2}$. However, for the category PlankGT200m (Plankton below 200-m depth), the acoustic abundance values were clearly the highest of all four years in 2016, with an average $s_{\mathrm{A}}$-value as high as 41.78 $\mathrm{m}^{2} \mathrm{nmi}^{-2}$, while median $s_{\mathrm{A}}$ was $26.15 \mathrm{~m}^{2} \mathrm{nmi}^{-2}$.

In all years, the category 0 -group fishes were reasonably numerous in the upper $200 \mathrm{~m}$ of the water column, but mainly on the west side of the Spitzbergen archipelago (Fig. 4a). However, in some years their range extended somewhat to the northeast, but only in one year were considerable amounts observed in Hinlopen Strait and northwards. The 0-group is normally associated with the epipelagic zone, where they feed on zooplankton, e.g., the small crustacean copepod Calanus finmarchicus and its congeners $C$. glacialis and $C$. hyperboreus, which are present in these waters as well. Therefore, their abundance deeper in the water column as derived from the acoustic data was extremely low in all years (Fig. 4b). The 0-group was dominated by redfish (Sebastes spp.) but also included cod, haddock, capelin, polar cod, and herring (Clupea harengus).

Capelin is important prey for Atlantic cod (see Bogstad et al. 2015) as well as some of the whale species (Christensen et al. 1992a; Haug et al. 2002; Windsland et al. 2007). Densities were studied by acoustic methods along the cruise tracks, where acoustic backscatter was allocated to capelin and where acoustic characteristics and/or catches of capelin in trawl hauls from relevant depths made the presence of capelin likely. However, the lack of a systematic area coverage made abundance estimation impossible. In general, low densities of capelin were encountered in the survey area all four years, although a few individuals were caught in many of the pelagic and demersal trawl hauls. In 2014, scattered concentrations of capelin were recorded acoustically, most notable at about $78.5^{\circ} \mathrm{N}$ on the west coast shelf break as well as north of Hinlopen Strait. In 2015, 2016 and 2017 only very scattered capelin concentrations were found. Capelin concentrations vary considerably within this area, since previous studies have found this species both in high concentrations and practically absent in certain years.

\section{Spatial overlap between rorquals and prey}

The proportion of co-occurrence was calculated for onedimensional directional distances spanning $2,4,6, \ldots$, $50 \mathrm{~km}$ from the whale sighting position (see details in Text 1 of EMS.pdf). The total numbers of whale sighting positions were 40 for minke whales, 79 for fin whales, and 53 for blue whales over the four years studied. With increasing distance from the whale sighting, the proportion of spatial overlap between whale and prey increased as shown in Figs. 5, 6, and 7 and in EMS_1.xlsx. Solid and dashed lines represent proportions of overlap between real whale and prey presences and proportions between simulated re-assigned data and prey presences, respectively. The difference between solid and dashed lines corresponds to the disparity of probabilities given by observation and simulation. By assessment using a two-sided probability test, the proportion indicating $p<0.05$ was noticed by symbol $\times$ on the solid line. This suggests that the occurrence of a whale sighting in proximity of the prey in question did not occur by chance.

Figure 5a shows that the overlaps between minke whales and Plankton were not similar between observed and simulated data for the distance ranges of 2-8 km, 26-34 km, and $48-50 \mathrm{~km}$ for the upper 200-m depth layer. In these ranges the null hypothesis could be rejected, suggesting that the occurrence of a minke whale sighting in proximity of the category Plankton did not occur by chance. Below 200-m depth, similar comparisons showed no significant differences, implying that any spatial overlap of predator and the prey item over larger distances were coincidental. Figure $5 b$, which compares minke whales and Atlantic cod, reveals significant differences between observed and simulated data for the 2-4-km distances at depths below $200 \mathrm{~m}$ (i.e., co-occurrence is not coincidental), while no significant differences were detected in the upper 200-m layer. In Fig. 5c (minke whale versus 0 -group fish) there are significant differences (and thus non-coincidental co-occurrence) between observed and simulated data for the 2-8-, 26-40-, and 48-50-km distances in the upper 200-m depths, and for the 4-km distance below $200 \mathrm{~m}$.

For fin whales (Fig. 6), only the comparison with 0-group fish indicated significant differences between observed and simulated data (at 2-km distance in the upper $200 \mathrm{~m}$ ); all 
(a) Proportion of minke whale - plankton overlap

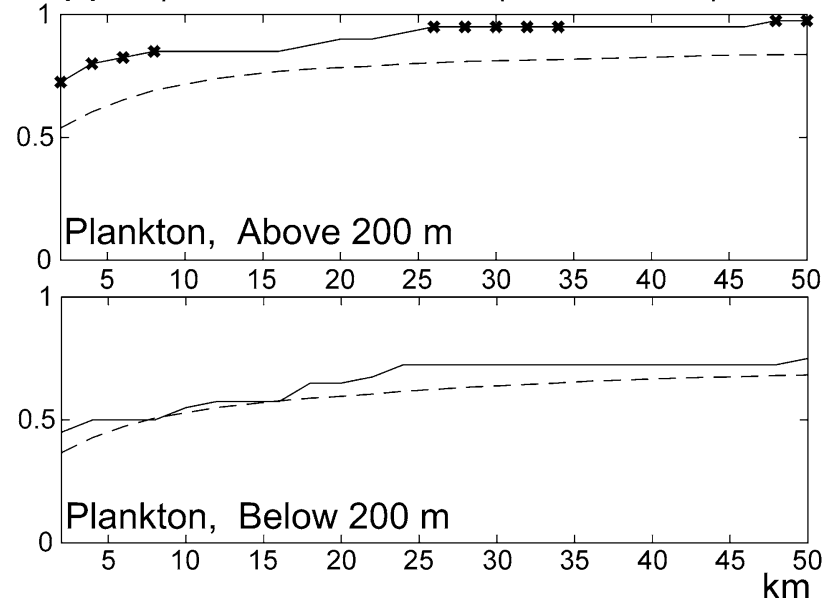

(b) Proportion of minke whale - cod overlap

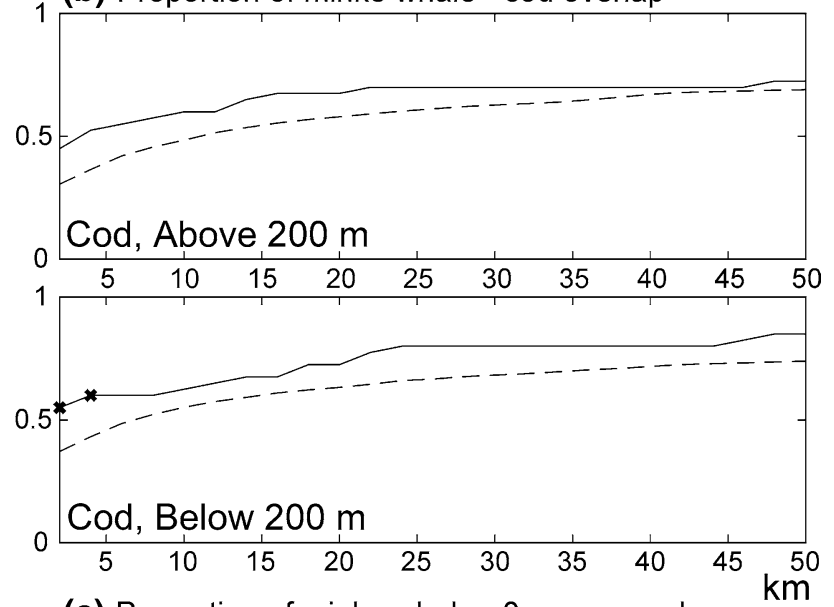

(c) Proportion of minke whale - 0-group overlap

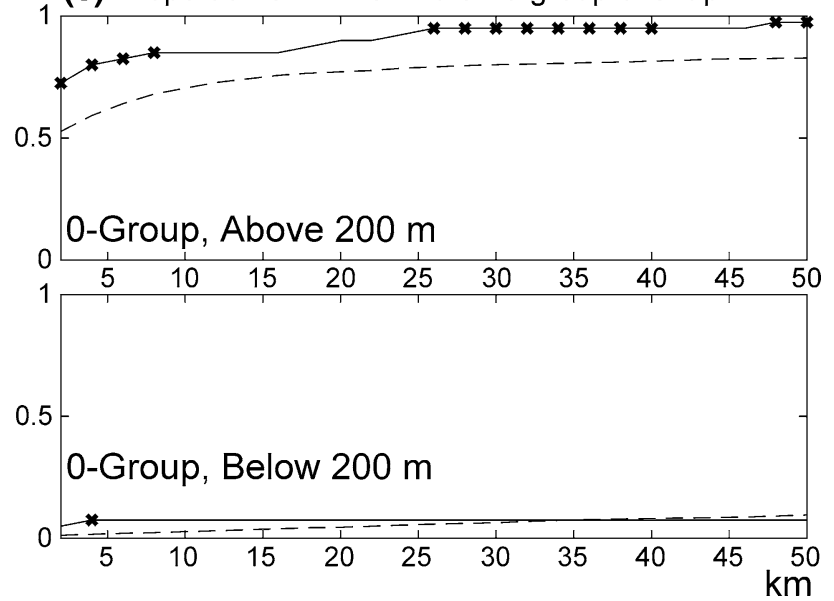

Fig. 5 Proportion of positive spatial overlap of minke whale sightings and the presence of plankton (a), cod (b), and 0-group fish (c). Results are given for the upper (10-200 m) depth layer and for the layer below $200 \mathrm{~m}$. Solid lines represent observed proportions of overlap, while dashed lines represent simulated data. Significant differences between the two models are indicated by $x$ (a) Proportion of fin whale - plankton overlap
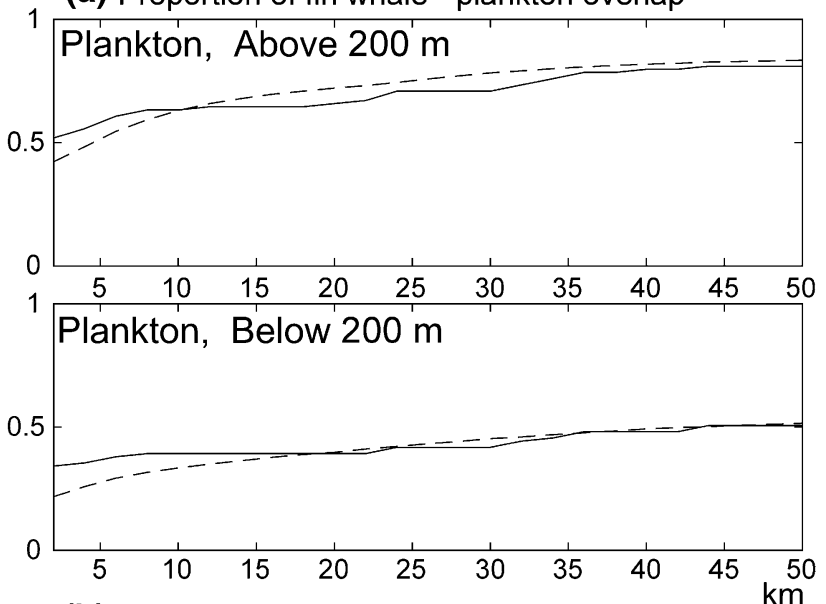

(b) Proportion of fin whale - cod overlap

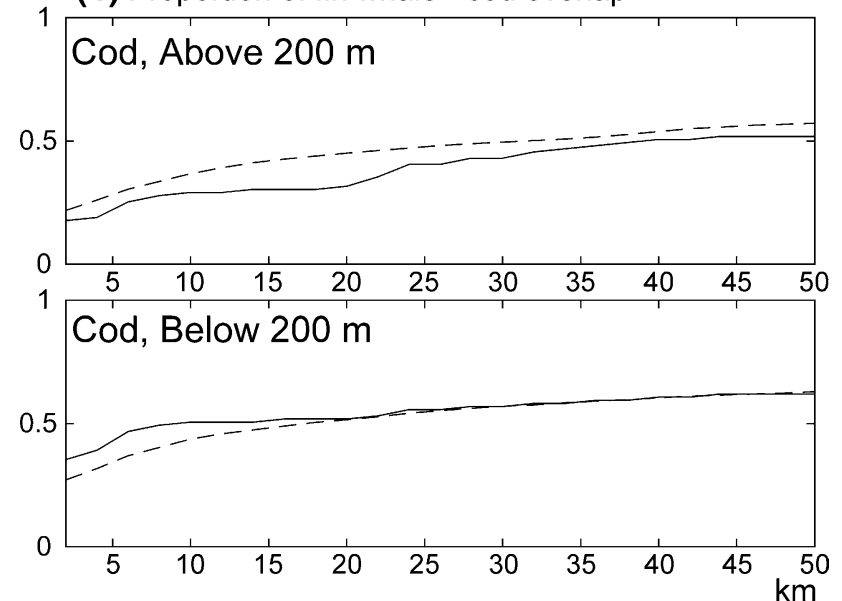

(c) Proportion of fin whale - 0-group overlap

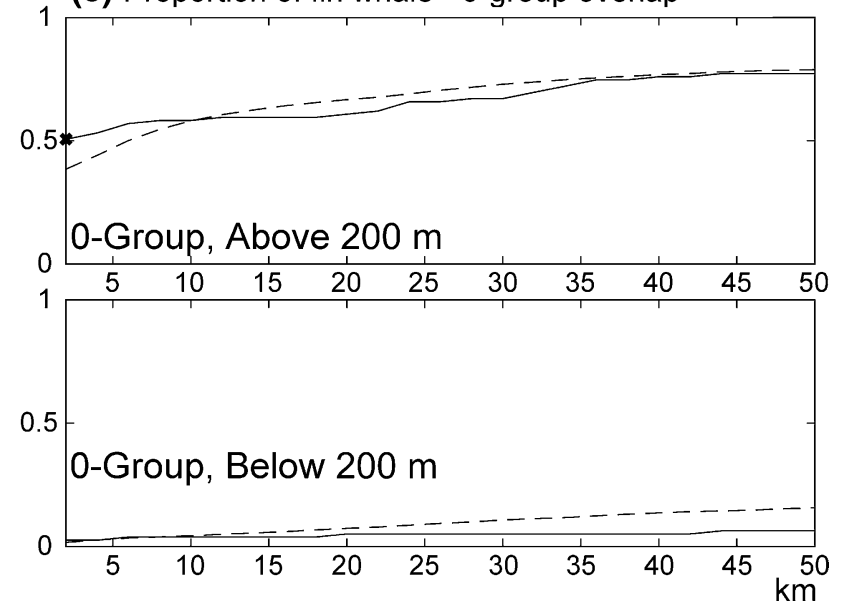

Fig. 6 Proportion of positive spatial overlap of fin whale sightings and the presence of plankton (a), cod (b), and 0-group fish (c). Results are given for the upper (10-200 m) depth layer and for the layer below $200 \mathrm{~m}$. Solid lines represent observed proportions of overlap, while dashed lines represent simulated data. Significant differences between the two models are indicated by $x$ 
(a) Proportion of blue whale - plankton overlap

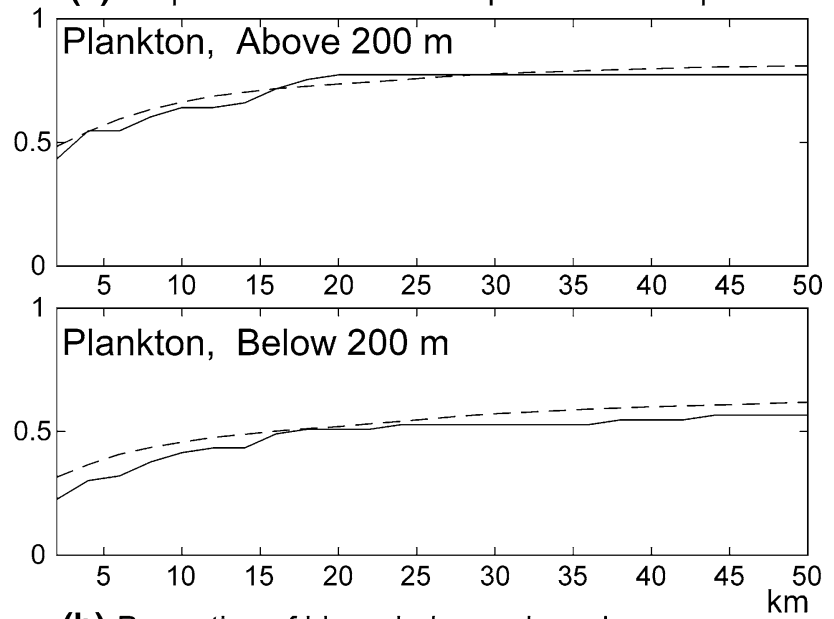

(b) Proportion of blue whale - cod overlap
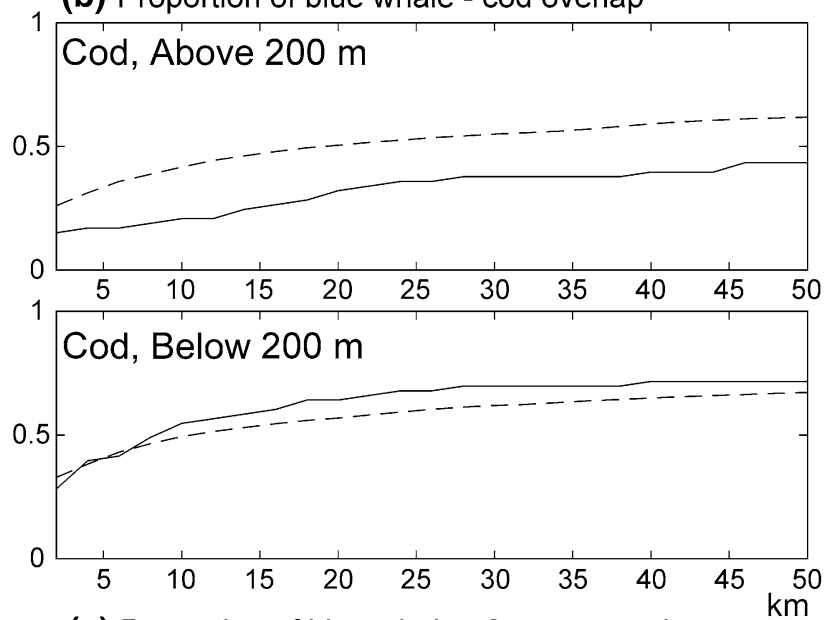

(c) Proportion of blue whale - 0-group overlap
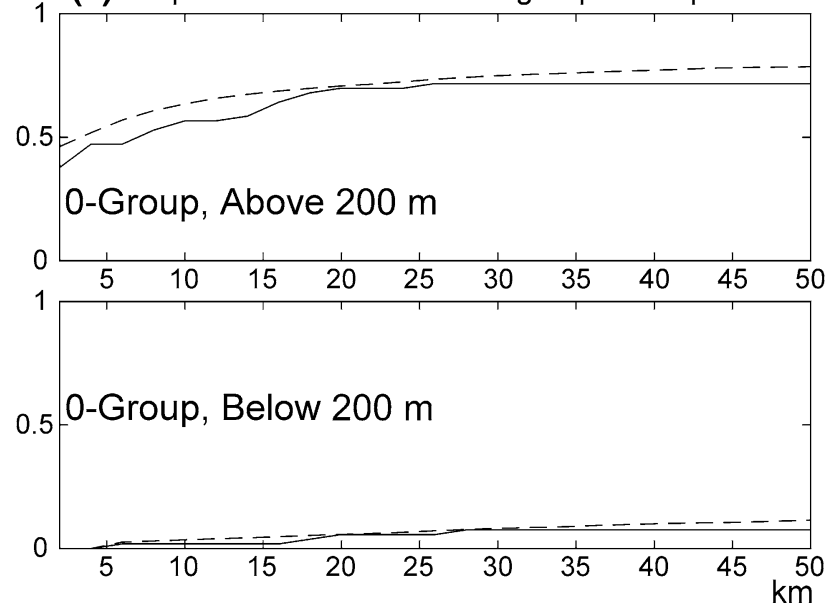

Fig. 7 Proportion of positive spatial overlap of blue whale sightings and the presence of plankton (a), cod (b), and 0-group fish (c). Results are given for the upper $(10-200 \mathrm{~m})$ depth layer and for the layer below $200 \mathrm{~m}$. Solid lines represent observed proportions of overlap, while dashed lines represent simulated data. Significant differences between the two models are indicated by $x$ remaining comparisons (with 0-group fish at depths below $200 \mathrm{~m}$ and for Plankton and Atlantic cod at all depths) suggest that any spatial overlap of predator and prey at any distance was coincidental. The latter is true also for blue whales (Fig. 7), where no comparison yielded significant differences between the observed and simulated data.

\section{Test of independence between rorquals and prey}

For 25-, 50-, and 100-km grid data (EMS_3.xlsx), a two-way table was generated, which includes counted numbers where abundance was defined as either present (1) or absent (0). The analyses were performed for the rorquals versus Plankton, Cod, or 0-group fishes for each depth strata, resulting in a total of 475 grid cells for $25 \mathrm{~km}, 239$ grid cells for $50 \mathrm{~km}$, and 120 grid cells for $100 \mathrm{~km}$ (Table 1).

For the depth stratum above $200 \mathrm{~m}$, the hypothesis of independent distribution was rejected between minke whales and all examined prey items for 50- and $100-\mathrm{km}$ spans; below $200 \mathrm{~m}$, the hypothesis of independent distribution was rejected between minke whales and cod for $100 \mathrm{~km}$ (Table 2). All remaining $p$-values indicate independent occurrence of whales and prey. We also applied the test to combinations of prey only. The calculated $p$-values are summarized in Table 3, which indicate that the independent hypothesis is rejected among all prey categories for both depth strata and for all spans.

\section{Logistic regression analyses}

In the logistic regression analyses of possible associations between the occurrence (presence or absence) of rorquals and the abundance of prey, log-transformations were used for the explanatory variable $x$ (corresponding to the observed amount of prey). We applied the model (2) to the 25-, 50-, and 100-km grid data (EMS_3.xlsx) for the two different depth strata. Table 4 summarizes the $p$-values given by a $z$-statistics test for the estimates of coefficient $\beta$ in the model. Associations for minke whale with cod in the upper $200 \mathrm{~m}$ and $25-\mathrm{km}$ span as well as all preys above $200 \mathrm{~m}$ and from cod below $200 \mathrm{~m}$ in 50- and 100-km spans were supported by the $p$-values. Furthermore, only one case of association for fin whale with cod below $200 \mathrm{~m}$ indicated $p<0.05$ in the $25-\mathrm{km}$ span.

For minke whale, the models with significant coefficients $\beta$ in the cases of $50-$ and $100-\mathrm{km}$ spans were: 
Table 1 Counted numbers for presence (1) or absence (0) of rorqual (minke, fin and blue) observations and $s_{\mathrm{A}}$-values of plankton, cod, and 0 -group fish. Two depth strata were considered: above $200 \mathrm{~m}$ (LE200 m) and below (200m - bottom)

\begin{tabular}{|c|c|c|c|c|c|c|c|c|c|c|}
\hline \multirow[t]{2}{*}{ Depth } & & \multicolumn{2}{|l|}{ Minke } & \multirow[t]{2}{*}{ Total } & \multicolumn{2}{|l|}{ Fin } & \multirow[t]{2}{*}{ Total } & \multicolumn{2}{|l|}{ Blue } & \multirow[t]{2}{*}{ Total } \\
\hline & & $1(25)$ & $0(214)$ & & $1(41)$ & 0 (198) & & $1(28)$ & $0(211)$ & \\
\hline \multicolumn{11}{|l|}{ LE $200 \mathrm{~m}$} \\
\hline \multirow[t]{2}{*}{ Plankton } & 1 & 24 & 145 & 169 & 32 & 137 & 169 & 22 & 147 & 169 \\
\hline & 0 & 1 & 69 & 70 & 9 & 61 & 70 & 6 & 64 & 70 \\
\hline \multirow[t]{2}{*}{ Cod } & 1 & 17 & 88 & 105 & 18 & 87 & 105 & 12 & 93 & 105 \\
\hline & 0 & 8 & 126 & 134 & 23 & 111 & 134 & 16 & 118 & 134 \\
\hline \multirow[t]{2}{*}{ 0-Group fish } & 1 & 24 & 136 & 160 & 28 & 132 & 160 & 20 & 140 & 160 \\
\hline & 0 & 1 & 78 & 79 & 13 & 66 & 79 & 8 & 71 & 79 \\
\hline \multicolumn{11}{|l|}{$200 \mathrm{~m}-$ bottom } \\
\hline \multirow[t]{2}{*}{ Plankton } & 1 & 20 & 140 & 160 & 31 & 129 & 160 & 20 & 140 & 160 \\
\hline & 0 & 5 & 74 & 79 & 10 & 64 & 74 & 8 & 71 & 79 \\
\hline \multirow[t]{2}{*}{ Cod } & 1 & 17 & 102 & 119 & 25 & 94 & 119 & 16 & 103 & 119 \\
\hline & 0 & 8 & 112 & 120 & 16 & 104 & 120 & 12 & 108 & 120 \\
\hline \multirow[t]{2}{*}{ 0-Group fish } & 1 & 2 & 24 & 26 & 2 & 24 & 26 & 3 & 23 & 26 \\
\hline & 0 & 23 & 190 & 213 & 39 & 174 & 213 & 25 & 188 & 213 \\
\hline
\end{tabular}

Table 2 Calculated $p$ values for chi-square tests to assess whether the co-occurrence (within a cell formed by $25-, 50-$, or $100-\mathrm{km}$ grids on a transect line) of rorquals and their prey was independent. Two depth strata were considered : above $200 \mathrm{~m}$ (LE 200m) and below $200 \mathrm{~m}$ (200m-bottom)

\begin{tabular}{|c|c|c|c|c|c|}
\hline Grid cells & Depth & Prey & Minke & Fin & Blue \\
\hline \multirow[t]{6}{*}{$25 \mathrm{~km}$} & \multirow[t]{3}{*}{$<$ LE $200 \mathrm{~m}$} & Plankton & 0.2102 & 0.8637 & 0.4258 \\
\hline & & Cod & 0.1013 & 0.3382 & 0.9194 \\
\hline & & 0-Group fish & 0.1034 & 0.8026 & 0.694 \\
\hline & \multirow{3}{*}{$\begin{array}{l}200 \mathrm{~m}-\text { bot- } \\
\text { tom }\end{array}$} & Plankton & 0.499 & 0.4706 & 0.7468 \\
\hline & & Cod & 0.2299 & 0.6159 & 0.5307 \\
\hline & & 0-Group fish & 1 & 0.7241 & 1 \\
\hline \multirow[t]{6}{*}{$50 \mathrm{~km}$} & \multirow[t]{3}{*}{ LE 200 m } & Plankton & 0.00685 & 0.3443 & 0.56506 \\
\hline & & Cod & 0.0188 & 1 & 1 \\
\hline & & 0-Group fish & 0.002374 & 0.9848 & 0.7468 \\
\hline & \multirow{3}{*}{$\begin{array}{l}200 \mathrm{~m} \text { - bot- } \\
\text { tom }\end{array}$} & Plankton & 0.2143 & 0.2656 & 0.7468 \\
\hline & & Cod & 0.08671 & 0.1609 & 0.5307 \\
\hline & & 0-Group fish & 0.8815 & 0.28 & 1 \\
\hline \multirow[t]{6}{*}{100 km } & \multirow[t]{3}{*}{ LE $200 \mathrm{~m}$} & Plankton & 0.02931 & 0.2967 & 1 \\
\hline & & Cod & 0.05101 & 0.867 & 0.8664 \\
\hline & & 0-Group fish & 0.01321 & 0.8527 & 1 \\
\hline & \multirow{3}{*}{$\begin{array}{l}200 \mathrm{~m}-\text { bot- } \\
\text { tom }\end{array}$} & Plankton & 0.2067 & 0.4051 & 1 \\
\hline & & Cod & 0.05483 & 0.2798 & 0.7711 \\
\hline & & 0-Group fish & 0.916 & 0.8574 & 1 \\
\hline
\end{tabular}

Table 3 Calculated $p$-values for chi-square tests to assess whether the co-occurrence (within a cell formed by $25-, 50-$, and 100-km grids on a transect line) of different prey categories was independent. Two depth strata were cosidered: above $200 \mathrm{~m}$ (LE 200m) and below $200 \mathrm{~m}$ (200m - bottom)

\begin{tabular}{llll}
\hline Grid cells & Depth & LE 200 m & GT 200 m \\
\hline $25 \mathrm{~km}$ & Plankton vs cod & $<2.2 \mathrm{e}-16$ & $<2.2 \mathrm{e}-16$ \\
& Plankton vs 0-group fish & $<2.2 \mathrm{e}-16$ & 0.000174 \\
& Cod vs 0-group fish & $<2.2 \mathrm{e}-16$ & 0.01187 \\
$50 \mathrm{~km}$ & Plankton vs cod & $<2.2 \mathrm{e}-16$ & $<2.2 \mathrm{e}-16$ \\
& Plankton vs 0-group fish & $<2.2 \mathrm{e}-16$ & 0.0003509 \\
& Cod vs 0-group fish & $5.861 \mathrm{e}-16$ & 0.02101 \\
$100 \mathrm{~km}$ & Plankton vs cod & $2.48 \mathrm{e}-10$ & $2.05 \mathrm{e}-13$ \\
& Plankton vs 0-group fish & $<2.2 \mathrm{e}-16$ & 0.0074 \\
& Cod vs 0-group fish & $1.0 \mathrm{e}-9$ & 0.011 \\
\hline
\end{tabular}


Table 4 Logistic regression analyses of possible associations between rorquals (minke, fin and blue) and various prey categories. The calculated $p$-values for the estimates of coefficient $\beta$ of the applied model (2) in the cases of 25-, 50-, and 100-km grid cells are given. Two depth strata were considered: above $200 \mathrm{~m}$ (LE $200 \mathrm{~m}$ ) and below $200 \mathrm{~m}$ (GT $200 \mathrm{~m}$ )

\begin{tabular}{|c|c|c|c|c|c|c|}
\hline Grid cells & Depth & Prey & Minke & Fin & Blue & Number of cells \\
\hline \multirow[t]{6}{*}{$25 \mathrm{~km}$} & \multirow[t]{3}{*}{ LE $200 \mathrm{~m}$} & Plankton & 0.111 & 0.79 & 0.30 & 313 \\
\hline & & Cod & 0.0022 & 0.031 & 0.84 & 177 \\
\hline & & 0-Group fish & 0.22 & 0.75 & 0.88 & 296 \\
\hline & \multirow[t]{3}{*}{$200 \mathrm{~m}$-bottom } & Plankton & 0.39 & 0.31 & 0.36 & 285 \\
\hline & & Cod & 0.088 & 0.68 & 0.72 & 211 \\
\hline & & 0-Group fish & 0.38 & 0.22 & 0.73 & 31 \\
\hline \multirow[t]{6}{*}{$50 \mathrm{~km}$} & \multirow[t]{3}{*}{ LE $200 \mathrm{~m}$} & Plankton & 0.013 & 0.29 & 0.89 & 169 \\
\hline & & Cod & 0.0014 & 0.10 & 0.25 & 105 \\
\hline & & 0-Group fish & 0.03 & 0.90 & 0.24 & 160 \\
\hline & \multirow[t]{3}{*}{$200 \mathrm{~m}$-bottom } & Plankton & 0.20 & 0.17 & 0.43 & 160 \\
\hline & & Cod & 0.058 & 0.18 & 0.36 & 119 \\
\hline & & 0-Group fish & 0.82 & 0.13 & 0.79 & 26 \\
\hline \multirow[t]{6}{*}{$100 \mathrm{~km}$} & \multirow[t]{3}{*}{ LE $200 \mathrm{~m}$} & Plankton & 0.030 & 0.28 & 0.84 & 90 \\
\hline & & Cod & 0.0022 & 0.65 & 0.87 & 62 \\
\hline & & 0-Group fish & 0.058 & 0.72 & 0.55 & 86 \\
\hline & \multirow[t]{3}{*}{$200 \mathrm{~m}$ - bottom } & Plankton & 0.13 & 0.19 & 0.74 & 88 \\
\hline & & Cod & 0.021 & 0.21 & 0.44 & 68 \\
\hline & & 0-Group fish & 0.53 & 0.39 & 0.42 & 20 \\
\hline
\end{tabular}

Table 5 Causal inference by categorical data analyses: Calculated AIC values obtained for conditional combinations of predator $(\mathrm{W}=$ minke whales) and prey ( $\mathrm{PL}=$ plankton, $\mathrm{CD}=\mathrm{cod}, 0 \mathrm{gr}=0$-group fish). Only the upper $200 \mathrm{~m}$ depth layer was considered

\begin{tabular}{|c|c|c|c|c|c|c|c|c|c|}
\hline & & \multicolumn{8}{|c|}{ Response variable } \\
\hline & & W & & PL & & CD & & $0 \mathrm{gr}$ & \\
\hline \multirow{7}{*}{$\begin{array}{l}\text { Explanatory } \\
\text { variables }\end{array}$} & \multirow[t]{3}{*}{1} & PL & -9.58 & W & -9.58 & W & -4.57 & W & -12.17 \\
\hline & & $\mathrm{CD}$ & -4.57 & $\mathrm{CD}$ & -97.56 & PL & -97.56 & PL & -214.90 \\
\hline & & $0 \mathrm{gr}$ & -12.17 & Ogr & -214.90 & Ogr & -76.82 & CD & -76.82 \\
\hline & \multirow[t]{3}{*}{2} & PL, CD & -8.51 & W, CD & -96.97 & $\mathrm{~W}, \mathrm{PL}$ & -98.51 & $\mathrm{~W}, \mathrm{PL}$ & -209.79 \\
\hline & & PL, Ogr & -7.30 & $\mathrm{~W}, 0 \mathrm{gr}$ & -207.24 & $\mathrm{~W}, 0 \mathrm{gr}$ & -72.83 & W, CD & -78.67 \\
\hline & & $\mathrm{CD}, 0 \mathrm{gr}$ & -8.14 & $\mathrm{CD}, 0 \mathrm{gr}$ & -230.54 & PL, 0gr & -93.23 & PL, CD & -213.54 \\
\hline & 3 & $\mathrm{PL}, \mathrm{CD}, 0 \mathrm{gr}$ & -3.54 & $\mathrm{~W}, \mathrm{CD}, 0 \mathrm{gr}$ & -219.04 & $\mathrm{~W}, \mathrm{PL}, 0 \mathrm{gr}$ & -89.04 & W, PL, CD & -204.44 \\
\hline
\end{tabular}

50-km span:

Appearance probability of minke whale $=(1+\exp (-2.8+0.18 \times \text { Plankton upper } 200 \mathrm{~m}))^{-1}$,

Appearance probability of minke whale $=(1+\exp (-1.9+0.15 \times \operatorname{Cod} \text { upper } 200 \mathrm{~m}))^{-1}$,

Appearance probability of minke whale $=(1+\exp (-2.5+0.10 \times 0-\text { group fish upper } 200 \mathrm{~m}))^{-1}$, and

Appearance probability of minke whale $=(1+\exp (-2.2+0.08 \times \operatorname{Cod} \text { below } 200 \mathrm{~m}))^{-1}$. 
Fig. 8 Experiments to assess possible food-web flow dynamics between minke whales and prey by calculating AIC values using CATDAP for the relationships shown. a Relationship between minke whales and all prey categories of plankton (PL), cod (CD), and 0-group fish (0gr). b Case with exclusion of the link from minke whale to cod and 0-group fish. c Case with exclusion of the link from minke whale to cod. d Case with exclusion of the link from minke whale to 0-group fish

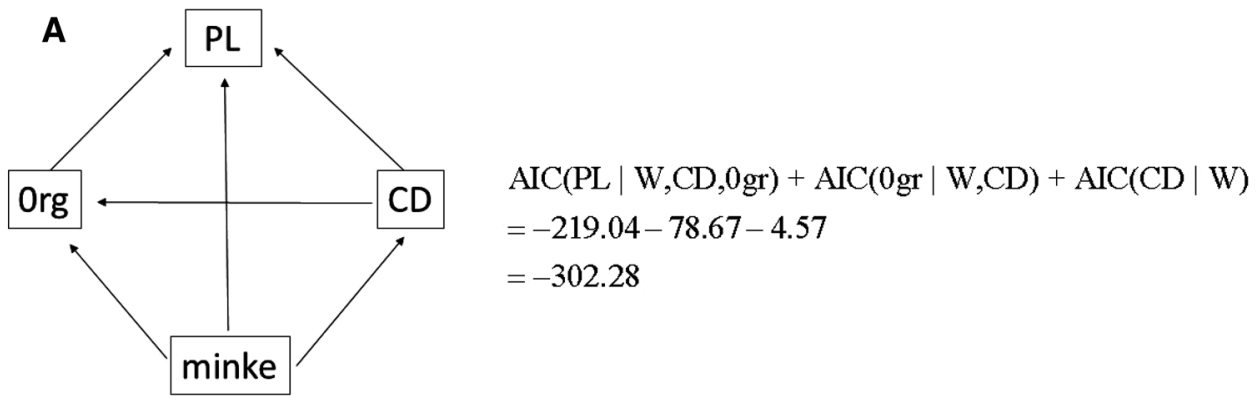

B

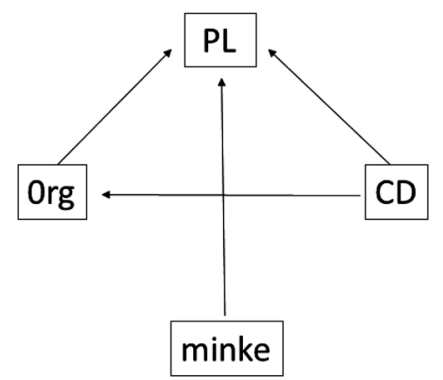

AIC(PL $\mid$ W,CD,0gr) + AIC(PL $\mid$ W)

$=-219.04-9.58$

$=-228.62$

C

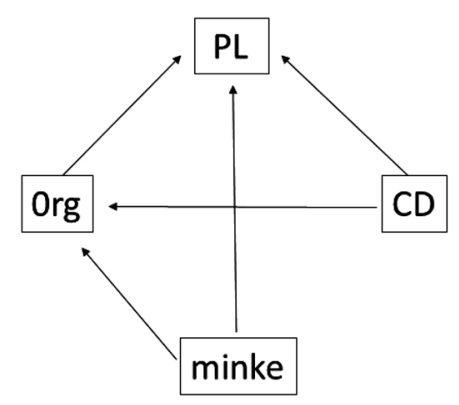

$\mathrm{AIC}(\mathrm{PL} \mid \mathrm{W}, \mathrm{CD}, 0 \mathrm{gr})+\mathrm{AIC}(0 \mathrm{gr} \mid \mathrm{W}, \mathrm{CD})$

$=-219.04-78.67$

$=-297.71$

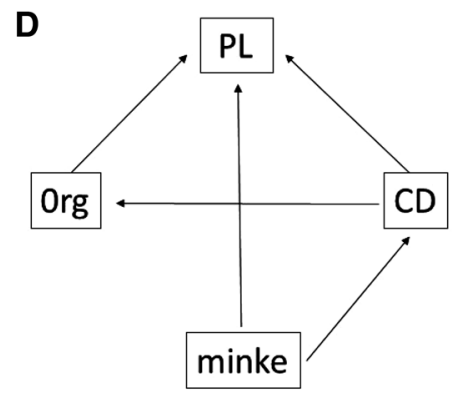

$\mathrm{AIC}(\mathrm{PL} \mid \mathrm{W}, \mathrm{CD}, 0 \mathrm{gr})+\mathrm{AIC}(0 \mathrm{gr} \mid \mathrm{CD})+\mathrm{AIC}(\mathrm{CD} \mid \mathrm{W})$

$=-219.04-76.82-4.57$

$=-300.43$

100-km span:

Appearance probability of minke whale $=(1+\exp (-2.2+0.17 \times \text { Plankton upper } 200 \mathrm{~m}))^{-1}$,

Appearance probability of minke whale $=(1+\exp (-1.4+0.17 \times \operatorname{Cod} \text { upper } 200 \mathrm{~m}))^{-1}$,

Appearance probability of minke whale $=(1+\exp (-1.9+0.094 \times 0-\text { group fish upper } 200 \mathrm{~m}))^{-1}$, and

Appearance probability of minke whale $=(1+\exp (-1.7+0.11 \times \text { Cod below } 200 \mathrm{~m}))^{-1}$. 


\section{Causal inference by categorical data analyses}

From the outputs of the chi-square testing (Table 2) and logistic regression analyses (Table 4), we inferred that there were significant associations between minke whales and prey in the upper 10-200-m depth, while no such associations were demonstrated for fin and blue whales. Therefore, the categorical data analyses using CATDAP were restricted to minke whales. CATDAP first calculated the conditional probability for each combination that included one response variable and 1-3 explanatory variables. Based on the conditional probabilities, the log-likelihoods were calculated to obtain the AIC values summarized in Table 5. Since the conditional probabilities for $P(A \mid B)$ and $P(B \mid A)$ are equivalent, the $A I C$ values will be the same for both alternatives as seen in Table 5. Low AIC values were used as a criterion to further investigate which explanatory variables are best associated with each response variable. Table 5 shows high association for 0 -group fish with minke whale, for the combination of cod and 0-group fish with Plankton, for the combination of minke whale and Plankton with Atlantic cod, and for Plankton with 0-group fish. To assess possible foodweb dynamics, we considered the directional relationship between minke whales and prey in various ways as shown in Fig. 8. By calculating AIC values using CATDAP, values for the relationships shown in Fig. 8a-d were obtained. The alternative presented in Fig. 8a gives the lowest AIC value and seems to be the most likely description of the food-web pathways in the area, while Fig. $8 \mathrm{~b}$ (removing the links from minke whale to cod and to 0-group fish) is the most unlikely.

\section{Discussion}

\section{Distribution of rorquals}

Observations made during late summer (August-September) in 2014-2017 are in line with other recent observations of possible northward range expansions of seasonally resident rorquals (see Vacquie-Garcia et al. 2017; Storrie et al. 2018). Minke, fin and blue whales, and occasionally humpback whales, are now frequently observed in the waters to the west and north of Svalbard. Foraging is the reason why these whales migrate northwards every spring, attracted by the availability of particularly high-energetic food in the northern areas. The whales feed on a variety of species and sizes of crustaceans and fish, but in general, they prefer capelin, herring and krill (Christensen et al. 1992a; Haug et al. 2002; Windsland et al. 2007). Recent warming of water has resulted in a more poleward distribution of arcto-boreal and boreal zooplankton (Eriksen et al. 2017) and fish species (Fossheim et al. 2015; Kortsch et al. 2015), and it is assumed that such oceanographic and biological changes have contributed to changes observed in the distribution and abundance of several rorqual species during the past 30 years (Vikingsson et al. 2015). Observations made in regular Norwegian ecosystem surveys throughout the most recent decade have in fact shown that minke, fin and humpback whales now inhabit both Arctic and Atlantic waters, with the highest densities in Arctic waters north of the Polar Front during summer and autumn (Skern-Mauritzen et al. 2011; Ressler et al. 2015). Current abundance of blue whales in the north appear to have been somewhat more occasional (Pike et al. 2009).

The appearance of fin and blue whales is not a new phenomenon; both species were hunted by Norwegian whalers from Bear Island and northwards, including some of the areas to the west of Svalbard, from 1903 to 1912 (Christensen et al. 1992b), while minke whales have been hunted from the 1920s to the present day in areas that include waters both to the west and north of Svalbard (Haug et al. 2011, 2017). For fin whales, an apparent stock increase in the Northeast Atlantic (Vikingsson et al. 2015; NAMMCO 2018) may have resulted in expansion of fin whale distribution from their primary habitat around Iceland to the continental shelf-slope areas west and north of Svalbard, where they are currently more abundant. Even though the stock of Northeast Atlantic blue whales has not recovered to the same extent as the closely related fin whale, there seems to have been a significant increase in abundance as well as expansion in distribution with a more northward shift from their prime areas in Icelandic waters in recent years (Pike et al. 2009; Vikingsson et al. 2015). The surveys in 2016 and 2017 were more concentrated near the ice edge, which may have contributed to the absence of sightings of humpback whales. In Norwegian waters, humpback whales have traditionally been found in the areas around Bear Island during summer, subsequently moving into the Barents Sea south of Svalbard in autumn to feed on capelin (Christensen et al. 1992a, b; Øien 2009). If such patterns still prevail, they may explain the more variable appearance of humpback whales to the west and north of Svalbard in August-September. In the four survey years, only some scattered concentrations of capelin were observed in 2014, while in 2015-2017, the species was nearly absent in the area. This may also have contributed to the low abundance in 2015 and absence in 2016 and 2017 of humpback whales.

\section{Distribution of Atlantic cod}

There are much denser concentrations of Atlantic cod at and over the shelf than at mesopelagic depths outside the shelf-slope, which suggests that the main forage environment for Atlantic cod is demersal and partly pelagic food assemblages near the Svalbard coast. However, we have shown here, and in previous studies (Gjøsæter et al. 2017; 
Ingvaldsen et al. 2017; Knutsen et al. 2017), that a deep scattering layer extending from the shelf break toward the deep basins exists at mesopelagic depths west of Svalbard, and that adult Atlantic cod were found in that layer as well. Although this might have been a common phenomenon in this area in previous years, it could have gone undetected due to the lack of pelagic trawls at relevant depths and concentrations being so low that they are difficult to detect by simply looking at the echograms. The Atlantic cod sampled from trawl hauls over deep water had food in their stomachs. The stomach content varied from station to station but contained capelin and mesopelagic fish, in addition to fish remains that could not be determined to species, amphipods, krill, squid and other zooplankton organisms.

\section{Distribution of prey}

In the epipelagic zone, a shallow scattering layer found close to the surface $(\sim 0-50 \mathrm{~m})$ was a consistent feature for the region surveyed during all four years, but it also showed some year-to-year variation. An important constituent of this surface layer in 2014 was the 0-group of Sebastes spp. This 30-50-mm-long fish was a major contributor to the acoustic backscattering (Knutsen et al. 2017), particularly on the west side of Svalbard this year. North of Svalbard, the abundance of 0-group Sebastes spp. was considerably lower in 2014, while the krill species M. norvegica and T. inermis and the hyperiid amphipod T. libellula were observed in much higher abundances than further to the southwest (Knutsen et al. 2017). These species compensated for the reduced abundance of Sebastes spp. observed in the acoustic backscattering. The presence of 0-group fish in the epipelagic zone is a seasonal phenomenon. Most species present in this area spawn upstream to Svalbard in spring, and the larvae are transported into our study area in summer. In late autumn the offspring of demersal species descend to deeper water.

Zooplankton concentrations in the epipelagic water masses are also a seasonal phenomenon. As winter approaches, they move to deeper water to overwinter there. Some zooplankton and fish species also undertake diel vertical migrations (DVM), occupying mesopelagic depths during daytime and ascending toward the surface during night. DVM has been demonstrated to occur in the study area, but to a lesser degree than further south (Gjøsæter et al. 2017).

Typically observed in 2014 were many school-like structures in the shelf and slope waters around Hinlopen and the deeper region further to the north. This can also be seen from the acoustic data shown in Knutsen et al. (2017, their Fig. 4, Hinlopen transect, category "Weak_SC" basically corresponding to the Plankton category in this paper). Furthermore, the raw echograms of these structures in Knutsen et al. (2017, supplementary information) all show the characteristics of krill schools. It is assumed that even if krill and amphipods have very similar acoustic characteristics, both being elongate crustaceans, the latter group of animals, exemplified by the typical Arctic Themisto libellula, are not located in dense patches like krill but often in fainter nearsurface acoustic structures having a frequency response quite similar to that of krill (see Korneliussen et al. 2016). It is evident that several authors have observed T. libellula to be a key component of the near-surface habitat in Arctic waters (Percy 1993; Nilssen et al. 1995; Dalpadado et al. 2001). Ressler et al. (2015) stressed the fact that in the area of the western Barents Sea and around Svalbard, which they investigated, the integrated euphausiid biomass $\left(\mathrm{g} \mathrm{m}^{-2}\right)$ was about 11 times higher than the amphipod biomass. Such a result may depend on the gear and methods used and of course the types of distribution patterns used by these two different types of organisms. In general, larger T. libellula are capable of escaping behavior and might avoid smaller plankton nets. The investigations conducted by Nilssen et al. (1995) east of Svalbard suggest that T. libellula is sometimes the sole crustacean macrozooplankton in the near-surface "echo layers", while krill tend to be more important slightly deeper in the water column.

Macroplankton trawl data suggest a somewhat different picture after 2014. Data from the survey in 2016 show that $T$. libellula was more important on the northernmost slope stations toward the Arctic Ocean north of Svalbard (von Weissenberg 2018) compared to the presence of the two dominant krill species in the area, Meganyctiphanes norvegica and Thysanoessa inermis. On the shelf areas, on the other hand, particularly in the Hinlopen region, the relative krill abundances increased considerably, and here T. inermis was the most important of the krill species (von Weissenberg 2018).

From the 2014 data (Knutsen et al. 2017), it is evident that 0 -group fish can be a very important constituent in the epipelagic domain along the western Svalbard shelf and slope. A particular feature in 2017 was the finding that this component was also quite important in the Hinlopen area, extending northwards to the slope waters and closer to the ice edge (cf. Figure 4), as seen in the acoustic data from the upper $200 \mathrm{~m}$ for the category 0-group. During 2014, WP2 net hauls at the shelf, slope, and deep-water locations showed that the mesozooplankton biomass was very high, ranging from $\sim 10$ to $70 \mathrm{~g} \mathrm{DW} \mathrm{m}^{-2}$ (Knutsen et al. 2017). An important constituent in the upper $50 \mathrm{~m}$ was the copepodite stages CI- CV of $C$. finmarchicus and smaller copepods like Oithona. These groups were abundant in the upper $\sim 0-50 \mathrm{~m}$ as indicated by stratified Multinet tows during the first survey year, and they were likely associated with a marked subsurface fluorescence maximum observed at $\sim 25-30$-m depth both on Fram Strait side and north of the archipelago (Knutsen et al. 2017, their Fig. 3). It has been suggested that this was a general, although variable, feature through 
all four years of these investigations. This means that the 0 -group Sebastes spp. probably had sufficient food available to sustain growth and survival during this period in 2014. However, it also indicates that the period from August until roughly mid-September is an important recruitment period for Calanus spp. in these northern waters, although phytoplankton bloom conditions might slightly differ among localities (cf. Søreide et al. 2008). Overall, this implies that there were available resources of both planktonic algae and copepods that could be utilized by the two species of krill that are dominant in the region: the more omnivorous $\mathrm{Meg}$ anyctiphanes norvegica and the primarily herbivorous Thysanoessa inermis (cf. Dalpadado et al. 2008), but also for that matter by the primarily carnivorous Arctic amphipod $T$. libellula (Dalpadado et al. 2008; Noyon et al. 2011).

Although it is not very well known, for rorquals an obviously crucial matter is how the distribution pattern and schooling behavior of euphausiids compare with those of amphipods. The two key krill species in the Northern Atlantic are known to form schools (e.g., Kaartvedt et al. 2005; Ressler et al. 2015), while our own acoustic data from 2014 (Knutsen et al. 2017, Supplementary Material included) show clearly defined krill schools mostly at around 200-m depth on the northern Svalbard shelf and slope. The dominance of T. inermis on this northern shelf was documented (von Weissenberg 2018), and the acoustic signatures are very similar to what have been observed by Ressler et al. (2015) in similar regions of the Barents Sea. Since the krill found in these northern shelf and slope areas are actively schooling during this period of the year, they might be more accessible even at considerable depth and more energetically favorable for rorquals to prey on than organisms like the amphipod T. libellula, which might have a different vertical distribution pattern and infrequently aggregate into dense schools, somewhat similar to what has been shown for its congener Themisto gaudichaudii in Antarctic waters (Brierley et al. 1998). From previous studies in the area, we know that rorquals feed on krill but not on amphipods (Christensen et al. 1992a; Haug et al. 2002; Windsland et al. 2007).

\section{Whale vs prey associations}

The observed rorquals exhibited a relatively broad and overlapping distribution that included both shelf and shelf-slope areas. However, minke whales displayed a broader habitat niche than the other rorquals, which extended from more coastal regions to deep-water areas outside the continental shelf. A trench leading from the shelf-slope north of Svalbard to Hinlopen Strait seemed to attract all rorqual species (Fig. 1). This area was also rich with respect to both the Plankton (Fig. 3) and 0-group fish categories (Fig. 4) in the upper 200-m layers and in Cod (Fig. 2) in layers below $200 \mathrm{~m}$. In general, minke, fin and humpback whales often co-exist and share features like preferred depths for foraging and specific food preferences (e.g., Goldbogen et al. 2011; Friedlander et al. 2015; Keen 2017; Storrie et al. 2018). Blue whales are known to be associated with continental slopes but, as also observed in this study, are quite frequently observed in coastal and fjord environments in Svalbard waters, which according to previous work may be driven by the incursion of Atlantic Water and its associated krill into these fjords and shelf areas in recent years (see Storrie et al. 2018).

In several previous studies, prey density distribution and environmental descriptors have been used as explanatory factors to describe rorqual distribution on different feeding grounds (e.g., Friedlaender et al. 2006; Ingram et al. 2007; Laidre et al. 2010; Skern-Mauritzen et al. 2011; Anderwald et al. 2012; Hazen et al. 2015; Ressler et al. 2015; Volkenandt et al. 2016; Fossette et al. 2017; Keen 2017). In some cases, no coupling or only very weak coupling could be documented (Skern-Mauritzen et al. 2011; Nøttestad et al. 2014), which could be due to mismatches in spatial and/or temporal resolution of the data. Our analyses of fin and blue whales in Svalbard waters seem to be in line with the latter, since spatial overlap or association between these predators and their potential prey were coincidental in the survey area (see Figs. 6 and 7). While it is not well known how baleen whales detect prey aggregations in the open ocean, several prey features have been found to influence aggregation and feeding in rorqual species (e.g., Friedlaender et al. 2006; Laidre et al. 2010; Hazen et al. 2015; Fossette et al. 2017; Keen 2017). Examples of trophic niche partitioning by consumption of different proportions of shared prey have been demonstrated by Gavrilchuk et al. (2014) for sympatric rorqual species in the Northwest Atlantic. In their studies of sympatric feeding of blue and fin whales, Friedlaender et al. (2015) found differences in feeding performance (e.g., lunge frequency) that may represent unique predatory strategies to minimize competition yet maximize energy gain in sympatric feeding whales. Furthermore, high-volume krill patches below certain threshold depths have been suggested as optimal for foraging rorquals such as blue and fin whales (Laidre et al. 2010; Hazen et al. 2015; Keen 2017). We suggest that the observed hotspot of both blue and fin whales in the northbound trench in the shelf north of Hinlopen Strait (Fig. 1), which was also a hotspot for zooplankton in all survey years, provides optimal foraging conditions for the two species of whales.

While blue whales are known to feed exclusively on krill, fin and minke whales are also known to target fish (e.g., Christensen et al. 1992a; Haug et al. 2002; Windsland et al. 2007; Bogstad et al. 2015). Minke whales are the most opportunistic of the rorquals and may feed on schooling pelagic forage fishes as well as haddock and cod. In our study, significant predator-prey associations were observed 
between minke whales and Plankton as well as 0-group fish in the upper 200-m water depth and between minke whales and cod in depths below $200 \mathrm{~m}$ (Fig. 5a, b). In the upper layers, spatial overlap occurred between the minke whales and prey within $8 \mathrm{~km}$, but also over longer distances $(25-50 \mathrm{~km}$, Fig. 5c). From their study of spatial associations between baleen whales and forage fish in the Celtic Sea, Volkenandt et al. (2016) suggested that within the concept of prey detection and foraging on a local scale, a maximum distance between predator and prey of less than $10 \mathrm{~km}$ could be the limit of the baleen whale's detection range. Our results seem to indicate longer detection ranges in the relationship between minke whales and Plankton/0-group fish occurring in the upper 200-m water layers, while the detection range between minke whales and cod below 200-m depth was only up to $4 \mathrm{~km}$. The independent test and logistic regression analysis clarified the observed relationship between minke whales and prey in the upper 200-m depth and the relationship between minke whales and Atlantic cod below $200 \mathrm{~m}$. The relationship between minke whales and Atlantic cod was also supported from the categorical data analyses using CATDAP (Fig. 8). The best model (A) includes directional relationships for minke whale $\rightarrow$ Plankton, 0 -group fish, and cod; for Atlantic cod $\rightarrow 0$-group fish and Plankton; and for 0 -group fish $\rightarrow$ Plankton. The other three models (B-D) include minke whale $\rightarrow$ Plankton as well, but have fewer connections to other prey categories. Our interpretation of this is that Plankton, 0-group fish, and Atlantic cod are all influenced by minke whales. All previous diet studies of minke whales in Svalbard waters (from 1992 to 2004) indicated that the species forage on either krill or, when available, capelin and Atlantic cod in the area (Haug et al. 2002; Windsland et al. 2007; Bogstad et al. 2015). Since Atlantic cod expanded its northern limit and became much more abundant in Svalbard waters during 2010-2012 (Haug et al. 2017) it may well be that minke whales now feed on Atlantic cod in this area as previously observed for the species further south in the Barents Sea (see Haug et al. 2002). However, despite minke whales consuming gadoid fish species (such as Atlantic cod), they are not the prime preference of the species (Lindstrøm and Haug 2001). Thus the positive spatial association between minke whales and cod (and between fin whales and cod, as observed when the grid cell size was reduced to $25 \mathrm{~km}$ ) could also be a consequence of mutual interest in the same prey species-some competition for food between minke whales and cod in the northern areas has in fact been suggested (Bogstad et al. 2015). This indicates a positive association between fin whales and cod.

\section{Concluding remarks}

This study shows that rorquals, apart from minke whales, may have trouble locating prey patches of sufficient density to warrant feeding. The lack of predator-prey association between the large rorquals (humpback, fin and blue whales) and their prey may suggest that the prey density in the survey area was below the threshold for successful feeding, which varies among baleen whale species (Piatt and Methven 1992; Keen 2017). Larger rorquals appear to have higher thresholds than smaller rorquals such as the minke whale (Piatt and Methven 1992). The causality analysis, showing that the presence of cod increases the interaction strength between minke whales and their preferred prey (Plankton), may also indicate indirect predatory effects, specifically that the presence of Atlantic cod forces zooplankton and 0-group fish up in the water column, making them more readily available for minke whales. Accordingly, indirect effects may play an important role in the predator-prey dynamics in the Barents Sea ecosystem (e.g., Bogstad et al. 1997; Lindstrøm et al. 2009).

Supplementary Information The online version contains supplementary material available at https://doi.org/10.1007/s00300-021-02835-2.

Acknowledgements We gratefully acknowledge the skilled assistance provided by the Captain, crew, and whale observers on the RV Helmer Hanssen over the four years of these investigations. The Research Council of Norway is thanked for its financial support through the projects “The Arctic Ocean Ecosystem" (SI_ARCTIC, RCN 228896) and "The Nansen Legacy" (AeN, RCN 276730), and appreciation is also given to the Institute of Marine Research (IMR), Bergen. The work is a contribution to the Barents and Norwegian Sea Ecosystem Programmes at IMR.

Authors contributions TH, HG, and TK conceived and designed the study and conducted the field work. In subsequent analyses and interpretation of data, HKS was responsible for all statistical analyses. TH, $\mathrm{N} \varnothing$, and $\mathrm{SH}$ were responsible for the whale observation data, whereas HG and TK had the main responsibility for the prey abundance studies. All authors contributed to relevant discussions and the preparation of the manuscript. HKS presented a preliminary version of the results at a joint Russian-Norwegian symposium in Murmansk, Russia, in June 2018; a preliminary abstract is available in the symposium's proceedings: https://www.hi.no/hi/nettrapporter/imrpinro/2019/proceedingsof-the-18th-russian-norwegian-symposium-nr.-1-2019.

Funding Open access funding provided by Institute Of Marine Research.

\section{Declarations}

Conflict of interest The authors declare that they have no conflict of interest.

Ethical approval All applicable international, national, and/or institutional guidelines for the care and use of animals were followed. 
Open Access This article is licensed under a Creative Commons Attribution 4.0 International License, which permits use, sharing, adaptation, distribution and reproduction in any medium or format, as long as you give appropriate credit to the original author(s) and the source, provide a link to the Creative Commons licence, and indicate if changes were made. The images or other third party material in this article are included in the article's Creative Commons licence, unless indicated otherwise in a credit line to the material. If material is not included in the article's Creative Commons licence and your intended use is not permitted by statutory regulation or exceeds the permitted use, you will need to obtain permission directly from the copyright holder. To view a copy of this licence, visit http://creativecommons.org/licenses/by/4.0/.

\section{References}

Akaike H (1974) A new look at statistical model identification. IEEE Trans Autom Control AC 19:716-723. https://doi.org/10.1109/ TAC.1974.1100705

Anderwald P, Evans PG, Dyer R, Dale A, Peter J, Hoelzel AR (2012) Spatial scale and environmental determinants in minke whale habitat use and foraging. Mar Ecol Prog Ser 450:259-274. https:// doi.org/10.3354/meps09573

Årthun M, Eldevik T, Smedsrud LH, Skagseth $\varnothing$, Ingvaldsen RB (2012) Quantifying the influence of Atlantic heat on Barents Sea ice variability and retreat. J Clim 25:4736-4743. https://doi.org/ 10.1175/JCLI-D-11-00466.1

Blix AS, Folkow LP (1995) Daily energy expenditure in free living minke whales. Acta Physiol Scand 153:61-66. https://doi.org/10. 1111/j.1748-1716.1995.tb09834.x

Bogstad B, Gjøsæter H, Haug T, Lindstrøm U (2015) A review of the battle for food in the Barents Sea: cod vs marine mammals. Front Ecol Evol 3:29. https://doi.org/10.3389/fevo.2015.00029

Bogstad B, Hauge KH, Ulltang Ø (1997) MULTSPEC_-a multispecies model for fish and marine mammals in the Barents Sea. J North Atl Fish Sci 22:317-341. https://doi.org/10.2960/J.v22.a23

Brierley AS, Ward P, Watkins JL, Goss C (1998) Acoustic discrimination of Southern Ocean Zooplankton. Deep-Sea Res II 45:11551173. https://doi.org/10.1016/S0967-0645(98)00025-3

Christensen I, Haug T, Øien N (1992a) A review of feeding and reproduction in large baleen whales (Mysticeti) and sperm whales Physeter macrocephalus in Norwegian and adjacent waters. Fauna Norv Ser A 13:39-48

Christensen I, Haug T, Øien N (1992b) Seasonal distribution, exploitation, and present abundance of stocks of large baleen whales (Mysticeti) and sperm whales Physeter macrocephalus in Norwegian and adjacent waters. ICES J Mar Sci 49:341-355. https:// doi.org/10.1093/icesjms/49.3.341

Croll DA, Acevedo-Guiterrez A, Tershy BR, Urban-Ramirez J (2001) The diving behaviour of blue and fin whales: is dive duration shorter than expected based on oxygen stores? Comp Biochem Physiol Part A Mol Integr Physiol 129:797-809. https://doi.org/ 10.1016/s1095-6433(01)00348-8

Dalpadado P, Borkner N, Bogstad B, Mehl S (2001) Distribution of Themisto (Amphipoda) spp. in the Barents Sea and predator-prey interactions. ICES J Mar Sci 58:876-895. https://doi.org/10.1006/ jmsc. 2001.1078

Dalpadado P, Yamaguchi A, Ellertsen B, Johannessen S (2008) Trophic interactions of macro-zooplankton (krill and amphipods) in the Marginal Ice Zone of the Barents Sea. Deep-Sea Res II 55:22662274. https://doi.org/10.1016/j.dsr2.2008.05.016

Dalpadado P, Ingvaldsen RB, Stige LC, Bogstad B, Knutsen T, Ottersen G, Ellertsen B (2012) Climate effects on Barents Sea ecosystem dynamics. ICES J Mar Sci 69:1303-1316. https://doi. org/10.1093/icesjms/fss063
Dingsør GE (2005) Estimating abundance indices from the international 0-group fish survey in the Barents Sea. Fish Res 72:205218. https://doi.org/10.1016/j.fishres.2004.11.001

Engås A, Godø OR (1989) Escape of fish under the fishing line of a Norwegian sampling trawl and its influence on survey results. J Conseil Int Pour l'Explor Mer 45:269-276

Eriksen E, Skjoldal HR, Gjøsæter H, Primicerio R (2017) Spatial and temporal changes in the Barents Sea pelagic compartment during the recent warming. Prog Oceanogr 151:206-226. https://doi.org/ 10.1016/j.pocean.2016.12.009

Foote KG, Knudsen HP, Vestnes G, MacLennan DN, Simmonds EJ (1987) Calibration of acoustic instruments for fish density estimation: A practical guide. ICES Coop Res Rep No. 144

Fossette S, Abrahams B, Hazen EL, Bograd SJ, Zilliacus KM, Calambokidis J, Burrows JA, Goldbogen JA, Harvey JT, Marinovic B, Tershy B, Croll DA (2017) Resource partitioning facilitates coexistence in sympatric cetaceans in the California current. Ecol Evol 7:9085-9097. https://doi.org/10.1002/ece3.3409

Fossheim M, Primicerio R, Johannesen E, Ingvaldsen RB, Aschan MM, Dolgov AV (2015) Recent warming leads to a rapid borealization of fish communities in the Arctic. Nat Clim Change 5:673-677. https://doi.org/10.1038/nclimate2647

Friedlaender AS, Halpin PN, Qian SS, Lawson GL, Wiebe PH, Thiele D, Read AJ (2006) Whale distribution in relation to prey abundance and oceanographic processes in shelf waters of the Western Antarctic Peninsula. Mar Ecol Prog Ser 317:297-310. https://doi. org/10.3354/meps317297

Friedlaender AS, Goldbogen JA, Hazen EL, Calambokidis J, Southall BL (2015) Feeding performance by sympatric blue and fin whales exploiting a common prey resource. Mar Mamm Sci 31:345-354. https://doi.org/10.1111/mms.12134

Gavrilchuk K, Lesage V, Ramp C, Sears R, Berube M, Bearhop S, Beauplet G (2014) Trophic niche partitioning among sympatric baleen whale species following the collapse of groundfish stocks in the Northwest Atlantic. Mar Ecol Prog Ser 487:285-301. https://doi.org/10.3354/meps10578

George JC, Druckenmiller ML, Laidre KL, Suydam R, Person B (2015) Bowhead whale body condition and links to summer sea ice and upwelling in the Beaufort Sea. Prog Oceanogr 136:250-262. https://doi.org/10.1016/j.pocean.2015.05.001

Gjøsæter H, Wiebe PH, Knutsen T, Ingvaldsen R (2017) Evidence of diel vertical migration of mesopelagic sound-scattering organisms in the Arctic. Front Mar Sci 4:332. https://doi.org/10.3389/ fmars.2017.00332

Godø OR, Valdemarsen JW, Engås A (1993) Comparison of efficiency of standard and experimental juvenile gadoid sampling trawls. ICES Mar Sci Symp 196:196-201

Goldbogen JA, Calambokidis J, Oleson E, Potvin J, Pyenson ND, Schorr G, Shadwick RE (2011) Mechanics, hydrodynamics and energetics of blue whale lunge feeding: efficiency dependence on krill density. J Exp Biol 214:131-146. https://doi.org/10.1242/ jeb.048157

Goldbogen JA, Friedlander AS, Calambokidis J, McKenna M, Simon M, Nowacek DP (2013) Integrative approaches to the study of baleen whale diving behavior, feeding performance, and foraging ecology. Bioscience 63:90-100. https://doi.org/10.1525/bio. 2013.63.2.5

Haug T, Bjørge A, Øien N, Ziryanov SV (2011) 7. Marine mammals; 7.1 Marine mammals of the Barents Sea. In: Jakobsen T, Ozhigin VK (eds) The barents sea; ecosystem, resources, management; half a century of Russian-Norwegian cooperation. Tapir Academic Press, Trondheim, pp 395-430

Haug T, Bogstad B, Chierici M, Gjøsæter H, Hallfredsson EH, Høines $\AA$, Hoel AH, Ingvaldsen RB, Jørgensen LL, Knutsen T, Loeng H, Naustvoll L-J, Røttingen I, Sunnanå K (2017) Future harvest of living resources in the Arctic Ocean of the Nordic and Barents 
Seas: a review of possibilities and constraints. Fish Res 188:3857. https://doi.org/10.1016/j.fishres.2016.12.002

Haug T, Lindstrøm U, Nilssen KT (2002) Variations in minke whale Balaenoptera acutorostrata diets in response to environmental changes in the Barents Sea. Sarsia 87:409-422. https://doi.org/ 10.1080/0036482021000155715

Hazen EL, Friedlaender AS, Goldbogen JA (2015) Blue whales (Balaenoptera musculus) optimize foraging efficiency by balancing oxygen use and energy gain as a function of prey density. Sci Adv 1:e1500469. https://doi.org/10.1126/sciadv.1500469

Heino M, Porteiro FM, Sutton TT, Falkenhaug T, Godø OR, Piatkowski U (2011) Catchability of pelagic trawls for sampling deep-living nekton in the mid-North Atlantic. ICES J Mar Sci 68:377-389. https://doi.org/10.1093/icesjms/fsq089

ICES (2015a) Calibration of acoustic Instruments, May 2015. ICES Coop Res Rep No. 326. https://doi.org/https://doi.org/10.17895/ ices.pub.5494

ICES (2015b) Manual for international pelagic surveys (IPS). Series of ICES survey protocols SISP 9-IPS. https://doi.org/https://doi. org/10.17895/ices.pub/7582

Ingram SN, Walshe L, Johnston D, Rogan E (2007) Habitat partitioning and the influence of benthic topography and oceanography on the distribution of fin and minke whales in the Bay of Fundy, Canada. J Mar Biol Assoc U K 87:149-156. https://doi.org/10.1017/S0025 315407054884

Ingvaldsen RB, Gjøsæter H, Ona E, Michalsen K (2017) Atlantic cod (Gadus morhua) feeding over deep water in the high Arctic. Polar Biol 40:2105-2111. https://doi.org/10.1007/s00300-017-2115-2

Juday C (1916) Limnological apparatus. Trans Wisconsin Acad Sci Arts Lett 18:566-592

Kaartvedt S, Røstad A, Fiksen Ø, Melle W, Torgersen T, Tiseth Breien M, Klevjer TA (2005) Piscivorous fish patrol krill swarms. Mar Ecol Prog Ser 299:1-5. https://doi.org/10.3354/meps299001

Katsura K, Sakamoto Y (1980) CATDAP, A Categorical Data Analysis Program Package. Computer Science Monograph, No 14, The Institute of Statistical Mathematics, Online ISSN: 1882-2274

Keen EM (2017) Aggregative and feeding thresholds of sympatric rorqual whales within a fjord system. Ecosphere 8:e01702. https:// doi.org/10.1002/ecs2.1702

Knudsen HP (2009) Long-term evaluation of scientific-echosounder performance. ICES J Mar Sci 66:1335-1340. https://doi.org/10. 1093/icesjms/fsp025

Knutsen T, Wiebe PH, Gjøsæter H, Ingvaldsen R, Lien G (2017) High latitude epipelagic and mesopelagic scattering layers - a reference for future arctic ecosystem change. Front Mar Sci 4:334. https:// doi.org/10.3389/fmars.2017.00334

Korneliussen RJ, Ona E, Eliassen I, Heggelund Y, Patel R, Godø OR, Giertsen C, Patel D, Nornes E, Bekkvik T, Knudsen HP, Lien G (2006) The large scale survey system-LSSS. Proceedings of the 29th Scandinavian Symposium on Physical Acoustics

Korneliussen RJ, Heggelund Y, Macaulay GJ, Patel D, Johnsen E, Eliassen IK (2016) Acoustic identification of marine species using a feature library. Methods Oceanogr 17:187-205. https://doi.org/ 10.1016/j.mio.2016.09.002

Korneliussen RJ, Ona E (2003) Synthetic echograms generated from the relative frequency response. ICES J Mar Sci 60:636-640. https://doi.org/10.1016/S1054-3139(03)00035-3

Kortsch S, Primicerio R, Fossheim M, Dolgov A, Aschan M (2015) Climate change alters the structure of arctic marine food webs due to poleward shifts of boreal generalists. Proc Royal Soc B 282:20151546

Kovacs KM, Lydersen C (2008) Climate change impacts on seals and whales in the North Atlantic Arctic and adjacent shelf areas. Sci Progr 91:117-150. https://doi.org/10.3184/003685008X324010

Kovacs KM, Lydersen C, Overland JE, Moore SE (2011) Impacts on changing sea-ice conditions on Arctic marine mammals. Mar Biodivers 41:181-194. https://doi.org/10.1007/ s12526-010-0061-0

Krafft BA, Melle W, Knutsen T, Bagøien E, Broms C, Ellertsen B, Siegel V (2010) Distribution and demography of Antarctic krill in the Southeast Atlantic sector of the Southern Ocean during the austral summer 2008. Polar Biol 33:957-968. https://doi.org/10. 1007/s0030-010-0774-3

Lagerquist BA, Stafford KM, Mate BM (2000) Dive characteristics of satellite-monitored blue whales (Balaenoptera musculus) off the central California coast. Mar Mamm Sci 16:375-391. https://doi. org/10.1111/j.1748-7692.2000.tb00931.x

Laidre KL, Heide-Jørgensen MP, Heagarty P, Cossio A, Bergstrøm B, Simon M (2010) Spatial associations between large baleen whales and their prey in West Greenland. Mar Ecol Prog Ser 402:269284. https://doi.org/10.3354/meps08423

Laidre KL, Stern H, Kovacs KM, Lowry LF, Moore SE, Regehr EV, Ferguson SH, Wiig $\varnothing$, Boveng P, Angliss RP, Born EW, Litovka D, Quakenbush L, Lydersen C, Vongraven D, Ugarte F (2015) Arctic marine mammal population status, sea ice habitat loss, and conservation recommendations for the $21^{\text {st }}$ century. Conserv Biol 29:724-737. https://doi.org/10.1111/cobi.12474

Lindstrøm U, Haug T (2001) Feeding strategy and prey selectivity in minke whales (Balaenoptera acutorostrata) foraging in the southern Barents Sea during early summer. J Cetacean Res Manag 3:238-249

Lindstrøm U, Smout S, Howell D, Bogstad B (2009) Modelling multispecies interactions in the Barents Sea ecosystem with special emphasis on minke whales, cod, herring and capelin. Deep Sea Res II 56:2068-2079. https://doi.org/10.1016/j.dsr2.2008.11.017

MacLennan DN, Fernandes PG, Dalen J (2002) A consistent approach to definitions and symbols in fisheries acoustics. ICES J Mar Sci 59:365-369. https://doi.org/10.1006/jmsc.2001.1158

Melle W, Abrahamsen M, Valdemarsen JW, Ellertsen B, Knutsen T (2006) Design and performance of a new macro-plankton trawl in combination with a multiple cod-end system. SCOR Working Group 115, Mini Symposium on Standards for the Survey and Analysis of Plankton. Plymouth

Misund OA, Heggland K, Skogseth R, Falck E, Gjøsæter H, Sundet J, Watne J, Lønne OJ (2016) Norwegian fisheries in the Svalbard zone since 1980. Regulations, profitability and warming waters affect landings. Polar Sci 10:312-322. https://doi.org/10.1016/j. polar.2016.02.001

Moore SE, Haug T, Vikingsson GA, Stenson GB (2019) Baleen whale ecology in arctic and subarctic seas in an era of rapid habitat alteration. Prog Oceanogr 176:102118. https://doi.org/10.1016/j. pocean.2019.05.010

Moore SE, Huntington HP (2008) Arctic marine mammals and climate change impact and resilience. Ecol Appl 18:S157-S165. https:// doi.org/10.1890/06-0571.1

Munk P (1993) Describing the distribution and abundance of small O-Group cod using ring-net sampling and echo-integration. ICES C.M. 1993/G:40:13 pp

NAMMCO (2018) Report of the 25th Scientific Committee meeting, MS Polarlys, Bergen-Troms $\varnothing, 12-16$ November 2018. NAMMCO SC/25/Report: $120 \mathrm{pp}$

Nedreaas K, Smedstad OM (1987) Abundance and distribution of postlarvae in the 0-group saithe survey in the North Sea and the Northeast Arctic in 1986 and 1987. ICES C.M. 1987/G:31: 27 pp

Nilssen KT, Haug T, Potelov V, Timoshenko YK (1995) Feeding habits of harp seals (Phoca groenlandica) during early summer and autumn in the northern Barents Sea. Polar Biol 15:485-493. https://doi.org/10.1007/BF00237462

Nøttestad L, Sivle LD, Krafft BA, Langård L, Anthonypillay V, Bernasconi M, Langøy H, Axelsen BE (2014) Ecological aspects of fin whale and humpback whale distribution during summer in the 
Norwegian Sea. Mar Ecol 35:221-232. https://doi.org/10.1111/ maec. 12075

Noyon M, Narcy F, Gasparini S, Mayzaud P (2011) Growth and lipid class composition of the Arctic pelagic amphipod Themisto libellula. Mar Biol 158:883-892. https://doi.org/10.1007/ s00227-010-1615-1

Øien N (2009) Distribution and abundance of large whales in Norwegian and adjacent waters based on ship surveys 1995-2001. NAMMCO Sci Publ 7:31-47. https://doi.org/10.7557/3.2704

Orlova EL, Dolgov AV, Renaud PE, Greenacre M, Halsband C, Ivshin VA (2015) Climatic and ecological drivers of euphausiid community structure vary spatially in the Barents Sea: relationships from a long time series (1952-2009). Front Mar Sci 1:74. https:// doi.org/10.3389/fmars.2014.00074

Orlova EL, Rudneva GB, Renaud PE, Eiane K, Savinov V, Yurko AS (2010) Climate impacts on feeding and condition of capelin (Mallotus villosus) in the Barents Sea. Evidence and mechanisms from a 30-year data series. Aquat Biol 10:105-118. https://doi.org/10. 3354/ab00265

Percy JA (1993) Reproduction and growth of the Arctic hyperiid amphipod Themisto libellula Mandt. Polar Biol 13:131-139. https://doi.org/10.1007/BF00238546

Piatt JF, Methven DA (1992) Threshold foraging behavior of baleen whales. Mar Ecol Prog Ser 84:205-210

Pike DG, Vikingsson GA, Gunnlaugsson T, Øien N (2009) A note on the distribution and abundance of blue whales (Balaenoptera musculus) in the Central and Northeast North Atlantic. NAMMCO Scientific Publications 7:19-29. https://doi.org/10.7557/3.2703

$\mathrm{R}$ version 3.5.1 (2018) R: A language and environment for statistical computing. R Foundation for Statistical Computing, Vienna, Austria. https://www.R-project.org/.

Ressler PH, Dalpadado P, Macaulay GJ, Handegård N, Skern-Mauritzen M (2015) Acoustic survey of euphausiids and models of baleen whale distribution in the Barents Sea. Mar Ecol Prog Ser 527:13-29. https://doi.org/10.3354/meps11257

Sakamoto Y, Akaike H (1978) Analysis of cross-classified data by AIC. Ann Inst Stat Math 30:185-197

Skeide R, Engås A, West CW (1997) Multisampler-a new tool for use in sampling trawls. In Shleinik V, Zaferman M (eds) Proceedings of the 7th Russian/Norwegian symposium: gear selection and sampling gears. Murmansk. pp 195-198.

Skern-Mauritzen M, Johannesen E, Bjørge A, Øien N (2011) Baleen whale distributions and prey associations in the Barents Sea. Mar Ecol Prog Ser 426:289-301. https://doi.org/10.3354/meps09027

Skjoldal HR, Prokopchuk I, Bagøien E, Dalpadado P, Nesterova V, Rønning J, Knutsen T (2019) Comparison of Juday and WP2 nets used in joint Norwegian-Russian monitoring of zooplankton in the Barents Sea. J Plankt Res 41(5):759-769. https://doi.org/10. 1093/plankt/fbz054

Solvang HK, Yanagihara H, Øien N, Haug T (2017) Temporal and geographical variation in body condition of common minke whales (Balaenoptera acutorostrata acutorostrata) in the Northeast Atlantic. Polar Biol 40:667-683. https://doi.org/10.1007/ s00300-016-1992-0

Solvang HK, Subbey S, Frank ASJ (2018) Causal drivers of Barents Sea capelin (Mallotus villosus) population dynamics on different time scales. ICES J Mar Sci 75:621-630. https://doi.org/10.1093/ icesjms/fsx 179

Søreide JE, Falk-Petersen S, Nøst Hegseth E, Hop H, Carroll ML, Hobson KA, Blachowiak-Samolyk K (2008) Seasonal feeding strategies of Calanus in the high-Arctic Svalbard region. Deep-Sea Res II 55:2225-2244. https://doi.org/10.1016/j.dsr2.2008.05.024
Storrie L, Lydersen C, Andersen M, Wynn RB, Kovacs KM (2018) Determining the species assemblage and habitat use of cetaceans in the Svalbard Archipelago, based on observations from 2002 to 2014. Polar Res 37:1-22. https://doi.org/10.1080/17518369. 2018.1463065

The Institute of Statistical Mathematics (2020) Package 'catdap' Categorical Data Analysis Program package, version 1.3.5. The Institute of Statistical Mathematics.

Vacquié-Garcia J, Lydersen C, Marques TA, Aars J, Ahonen H, SkernMauritzen M, Øien N, Kovacs KM (2017) Late summer distribution and abundance of ice-associated whales in the Norwegian High Arctic. Endang Species Res 32:59-70. https://doi.org/10. 3354/esr00791

Valdemarsen JW, Misund OA (1995) Trawl designs and techniques used by Norwegian research vessels to sample fish in the pelagic zone. In: Hylen A (ed) Precision and relevance of pre-recruit studies for fishery management related to fish stocks in the barents sea and adjacent waters. Proceedings of the sixth IMR-PINRO Symposium, Bergen, 14-17 June 1994. Institute of Marine Research, Bergen, Norway, pp 129-144.

Volkenandt M, O'Connor I, Guarini J, Berrow S, O’Donnell C (2016) Fine-scale spatial association between baleen whales and forage fish in the Celtic Sea. Can J Fish Aquat Sci 73:197-204. https:// doi.org/10.1139/cjfas-2015-0073

EW Weissenberg von (2018) Spatial structures of a high-Arctic macrozooplankton community. Helsinki October 2, 2018 Master of Science Thesis University of Helsinki Faculty of Biological and Environmental Sciences, pp 1-35

Vikingsson GA, Pike DG, Valdimarsson H, Schleimer A, Gunnlaugsson T, Silva T, Elvarsson BP, Mikkelsen B, Øien N, Desportes G, Bogason V, Hammond PS (2015) Distribution, abundance, and feeding ecology of baleen whales in Icelandic waters: have recent environmental changes had an effect? Front Ecol Evol 3:6. https:// doi.org/10.3389/fevo.2015.00006

Weikert H, John HC (1981) Experiences with a modified Be' multiple opening-closing plankton net. J Plankt Res 3:167-176

Wenneck TdL, Falkenhaug T, Bergstad OA (2008) Strategies, methods, and technologies adopted on the R.V. G.O. Sars MAR-ECO expedition to the Mid-Atlantic Ridge in 2004. Deep-Sea Res II 55:6-28. https://doi.org/10.1016/j.dsr2.2007.09.017

Williams R, Víkingsson GA, Gíslason A, Lockyer C, New L, Thomas L, Hammond PS (2013) Evidence for density-dependent changes in body condition and pregnancy rate of North Atlantic fin whales over four decades of varying environmental conditions. ICES J Mar Sci 70:1273-1280. https://doi.org/10.1093/icesjms/fst059

Windsland K, Lindstrøm U, Nilssen KT, Haug T (2007) Relative abundance and size composition of prey in the common minke whale diet in selected areas of the northeast Atlantic during 2000-04. J Cetacean Res Manag 9:167-178

Working Party 2 (1968) Smaller mesozooplankton. Report of working party no. 2. In: Fraser JH (ed) UNESCO Zooplankton Sampling Part II. Standardization of zooplankton sampling methods at sea. Monographs on Oceanographic Methodology, 2:153-174.

Zhukova NG, Nesterova VN, Prokopchuk IP, Rudneva GB (2009) Winter distributions of euphausiids (Euphausiacea) in the Barents Sea (200-2005). Deep Sea Res II 56:1959-1967. https://doi.org/10. 1016/j.dsr2.2008.11.007

Publisher's Note Springer Nature remains neutral with regard to jurisdictional claims in published maps and institutional affiliations. 